John Carroll University

Carroll Collected

2018 Faculty Bibliography

Faculty Bibliographies Community Homepage

2018

\title{
Biodiversity of terrestrial cyanobacteria of the South Ural region
}

Lira A. Gaysina

M. Akmullah Bashkir State Pedagogical University,

Markéta Bohunicka

University of Hradec Králové

Václava Hazukova

University of South Bohemia

Jeffrey R. Johansen

John Carroll University, johansen@jcu.edu

Follow this and additional works at: https://collected.jcu.edu/fac_bib_2018

Part of the Biology Commons

\section{Recommended Citation}

Gaysina, Lira A.; Bohunicka, Markéta; Hazukova, Václava; and Johansen, Jeffrey R., "Biodiversity of terrestrial cyanobacteria of the South Ural region" (2018). 2018 Faculty Bibliography. 60.

https://collected.jcu.edu/fac_bib_2018/60

This Article is brought to you for free and open access by the Faculty Bibliographies Community Homepage at Carroll Collected. It has been accepted for inclusion in 2018 Faculty Bibliography by an authorized administrator of Carroll Collected. For more information, please contact connell@jcu.edu. 


\title{
Biodiversity of terrestrial cyanobacteria of the South Ural region
}

\author{
Lira A. GAYSINA ${ }^{a *}$, Markéta BOHUNICKÁ ${ }^{b}$, \\ Václava HAZUKOVÁc \& Jeffrey R. JOHANSEN ${ }^{c}$ \\ ${ }^{a}$ Department of Bioecology and Biological Education, \\ M. Akmullah Bashkir State Pedagogical University, Ufa, Okt'yabrskoy revolucii 3a, \\ Republic of Bashkortostan, 450000, Russian Federation; All-Russian Research \\ Institute of Phytopathology, Moscow Region, Odintsovo district, B. Vyazyomy, \\ Institute street, 5, 143050, Russian Federation \\ ${ }^{b}$ Department of Biology, Faculty of Science, \\ University of Hradec Králové, Rokitanského 62, \\ 50003 Hradec Králové, Czech Republic \\ ${ }^{c}$ Faculty of Science, University of South Bohemia, Branišovská 31, \\ České Budějovice, 370 05, Czech Republic; Department of Biology, \\ John Carroll University, University Heights, 1 John Carroll Blvd., \\ Ohio 44118, USA
}

\begin{abstract}
South Ural is a territory with a unique geographical position and heterogeneous natural conditions. Unexplored biodiversity of the terrestrial cyanobacteria of this territory is very high. We undertook a fl oristic study covering all botanical-geographical zones of the Bashkiria and Bredinskiy district of the Chelyabinsk region. In a total of 85 soil samples collected, 56 species of cyanobacteria were identifi ed. The number of cyanobacteria was highest in the boreal-forest zone (39 species) and notably lower in the other zones $(18,29$, and 24 species for broad-leaved forest, forest steppe and steppe regions, respectively). Leptolyngbya voronichiniana, Leptolyngbya foveolarum, cf. Trichocoleus hospitus, Pseudophormidium hollerbachianum, Nostoc cf. punctiforme, Microcoleus vaginatus, Phormidium breve, Phormidium dimorphum, Phormidium corium, and Leptolyngbya cf. tenuis were detected in all studied zones. Trichormus variabilis and Cylindrospermum majus were detected in the forest zone, Phormidium ambiguum was typical for forest-steppe and steppe zones, Pseudophormidium hollerbachianum and Nostoc cf. commune were most abundant in the steppe. Humidity and heterogeneity of the substrate were likely the most important factors infl uencing terrestrial cyanobacteria diversity. For full understanding of the biodiversity of cyanobacteria in the South Urals, future molecular-genetic research is necessary.
\end{abstract}

Bashkiria / Leptolyngbya / Oculatella / Phormidium / soil / Trichocoleus 


\section{INTRODUCTION}

Despite the large number of floristic studies of terrestrial cyanobacteria already published (e.g. Adhikary, 2000; Vinogradova et al., 2000; Hauer, 2007, 2008; Neustupa \& Škaloud, 2010; Davydov, 2013), we still lack sufficient information about cyanobacterial biodiversity of many territories. This problem is very actual for many regions of Eurasia, including the mountain range of the South Urals.

The region of the South Ural is situated on the border of Europe and Asia and is characterized by unique natural conditions. The Republic of Bashkortostan (Bashkiria) occupies a large part of the South Ural between $51^{\circ} 31^{\prime} \mathrm{N}$ and $56^{\circ} 25^{\prime} \mathrm{N}$, and $53^{\circ} 10^{\prime} \mathrm{E}$ and $60^{\circ} 00^{\prime} \mathrm{E}$ (Alekseev et al., 1988) with an area of $143,000 \mathrm{~km}^{2}$ (Akhmadeyeva, 2003). Climatic features of Bashkortostan are explained by its position within the continent and the influence of geology that causes significant daily and annual amplitudes of temperature and precipitation (Tahaev, 1959).

Investigations of terrestrial cyanobacteria in the territory of the South Ural (mostly in Bashkiria) started in the 1960's. During long-term studies since the 1970s, phycologists from Bashkiria investigated cyanobacteria of agricultural lands (Sayfullina \& Minibaev, 1980), urban territories (Sukhanova \& Ishbirdin, 1997; Khaibulina et al., 2005), polluted areas (Kabirov \& Lubina, 1988; Kireeva et al., 2007; Sharipova, 1997, 2007; Kabirov et al., 2010), eroded lands (Dubovik, 2000, 2001, 2010), and caves (Abdullin \& Sharipova, 2004; Abdullin, 2009). However, the overall biodiversity of the cyanobacteria in natural ecosystems in the South Urals was studied very irregularly. Floristic studies were conducted mostly on foreststeppe, steppe zones and mountains (Kuzyakhmetov, 1981, 1992, 1998; Shmelev \& Kabirov, 2007; Bakieva et al., 2012). For example, up until the present we lacked information about cyanobacteria of the northern part of Bashkiria in the zones of boreal-forest and forest-steppe.

The aim of this paper is to study cyanobacterial communities in different types of ecosystems in the South-Ural.

\section{MATERIALS AND METHODS}

\section{Study sites}

Soil samples including soil crusts where available were taken in MayAugust 2010 according to standard methods of soil phycology (Gollerbach \& Shtina, 1969) from various botanical-geographical regions (zones), covering boreal and broad-leaved forests, forest-steppe, and steppes of the South Ural region. Botanicalgeographical regions of Bashkiria were established based on peculiarities of vegetation cover and geographic features (longitude, latitude, terrain, elevation and land use) (Alekseev et al., 1988). Each sample was a composite of seven subsamples collected from the site of around $2 \mathrm{~m}^{2}$ to a depth of $5 \mathrm{~cm}$. Samples were taken from the typical biotopes of the region as well as from the sites with heterogenic ecological conditions (e.g. riversides, ravines, paths), and sites with visible cyanobacterial growth and microbiotic crusts. A total of 81 samples were collected from 11 localities in the Republic of Bashkortostan. An additional four samples were taken in the steppes of the Bredinskiy district of the Chelyabinsk region (Fig. 1). Altogether, 


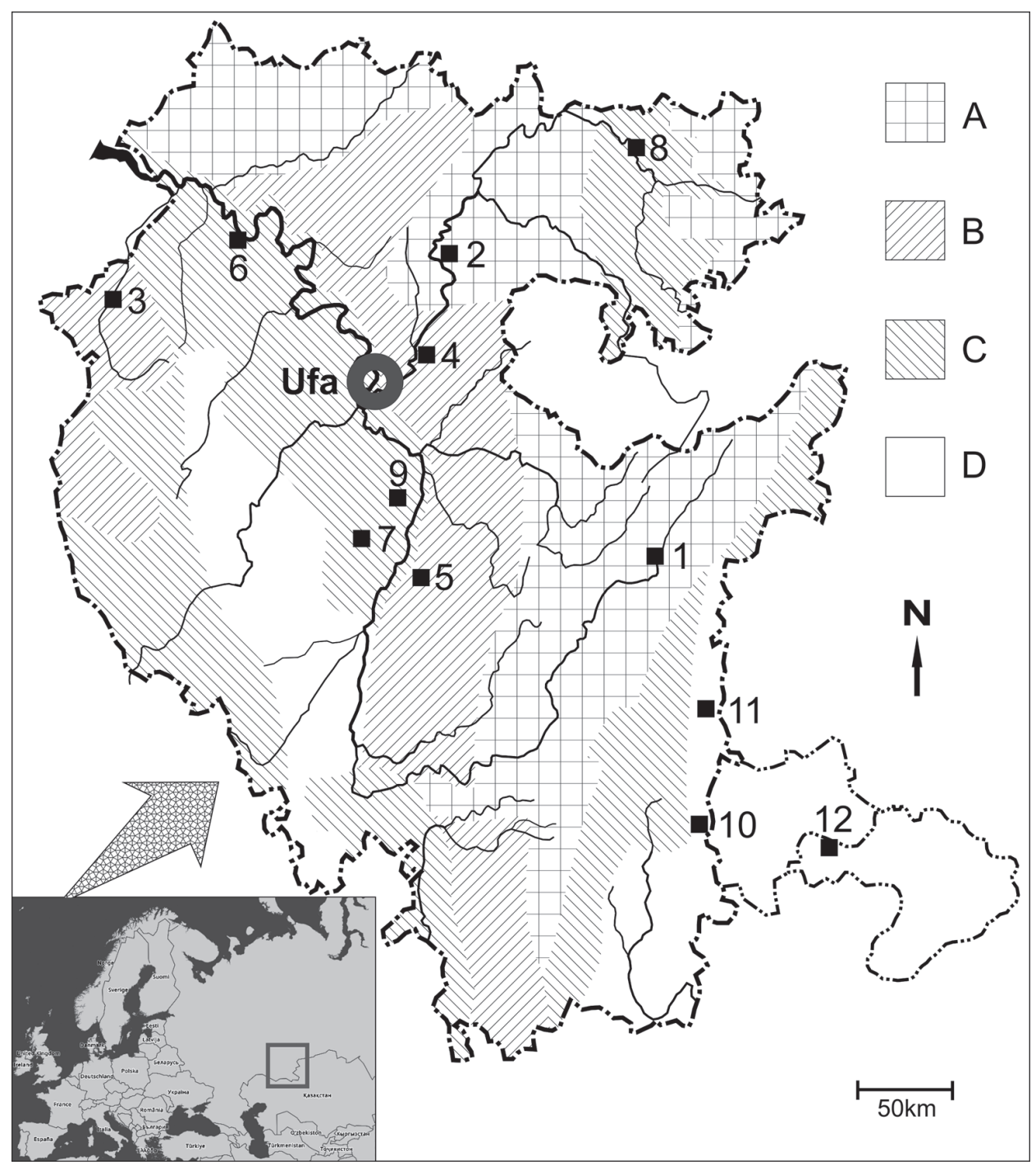

Fig. 1. Terrestrial cyanobacteria of the South Ural region: map of the sampling sites. Boreal forest zone (A): 1 - Beloretsk region, 2 - near Pavlovka village; Broad-leaved forest zone (B): 3 - Bakaly, 4 - Iglino, 5 - Krasnousolskiy; Forest-steppe zone (C): 6 - near Dyurtyuli town, 7 - near Tolbazy village, 8 - edge of Bolsheustikinskoye village, 9 - near Georgievka village; Steppe zone (D) of Bashkiria and Bredinskiy district of Chelyabinsk region: 10 - near Sibay town, 11 - near Yangelskiy village, 12 -near Arkaim monument.

85 samples of soil and microbiotic crusts from 12 localities were studied: 17 collected from boreal forests, 21 from broad-leaved forests, 29 from forest-steppes, and 18 from steppes (Table 1). 
Table 1. Comparisons of cyanobacteria in different zones in the territory of Bashkiria and the Bredinskiy district of the Chelyabinsk region, South Ural region, Russia. Frequency of occurrence is expressed using Braun-Blanquet scale with modifications: $1=0.1-5 \% ; 2=6-10 \% ; 3=11-20 \%$; $4=21-40 \% ; 5=41-60 \% ; 6=61-80 \% ; 7=81-100 \%$. BoF $=$ boreal forest, $\mathrm{BrF}=$ broad-leaved forest, $\mathrm{FS}=$ forest steppe, $\mathrm{S}=$ steppe, * = including the Bredinskiy district of the Chelyabinsk region

\begin{tabular}{|c|c|c|c|c|}
\hline \multirow[t]{2}{*}{ Taxon } & \multicolumn{4}{|c|}{$\begin{array}{c}\text { Botanical-geographical } \\
\text { region (zone) }\end{array}$} \\
\hline & $B o F$ & $B r F$ & $F S$ & $S^{*}$ \\
\hline \multicolumn{5}{|l|}{ Synechococcales } \\
\hline \multicolumn{5}{|l|}{ Pseudanabaenaceae } \\
\hline Pseudanabaena papillaterminata (Kiselev) Kukk & & & 1 & \\
\hline \multicolumn{5}{|l|}{ Leptolyngbyaceae } \\
\hline Leptolyngbya foveolarum (Rabenhorst ex Gomont) Anagnostidis \& Komárek & 5 & 4 & 5 & 4 \\
\hline Leptolyngbya cf. fragilis (Gomont) Anagnostidis \& Komárek & 2 & & & 2 \\
\hline Leptolyngbya cf. hansgirgiana Komárek in Anagnostidis & 4 & & & \\
\hline Leptolyngbya cf. subtilissima (Kützing ex Hansgirg) Komárek in Anagnostidis & 3 & & 2 & 2 \\
\hline Leptolyngbya $\mathrm{cf}$. tenuis (Gomont) Anagnostidis \& Komárek & 3 & 1 & 2 & 3 \\
\hline Leptolyngbya cf. nostocorum (Bornet ex Gomont) Anagnostidis \& Komárek & 2 & & & \\
\hline Leptolyngbya cf. notata (Schmidle) Anagnostidis \& Komárek & & & & 2 \\
\hline Leptolyngbya voronichiniana Anagnostidis \& Komárek & 4 & 6 & 5 & 5 \\
\hline Oculatella sp. 1 & & & 2 & \\
\hline Oculatella sp. 2 & & & 2 & \\
\hline Oculatella sp. 3 & & & & 2 \\
\hline cf. Trichocoleus hospitus (Hansgirg ex Forti) Anagnostidis & 2 & 6 & 4 & 4 \\
\hline \multicolumn{5}{|l|}{ Pleurocapsales } \\
\hline \multicolumn{5}{|l|}{ Hyellaceae } \\
\hline Myxosarcina cf. tatrica (Starmach) Komárek \& Anagnostidis & & 1 & & \\
\hline \multicolumn{5}{|l|}{ Chroococcales } \\
\hline \multicolumn{5}{|l|}{ Aphanothecaceae } \\
\hline Aphanothece stagnina (Spreng.) A.Braun & 2 & & & \\
\hline \multicolumn{5}{|l|}{ Chroococcaceae } \\
\hline Chroococcus varius A.Braun in Rabenhorst & & & 1 & \\
\hline \multicolumn{5}{|l|}{ Entophysalidaceae } \\
\hline Chlorogloea cf. purpurea Geitler & & 1 & 1 & 3 \\
\hline \multicolumn{5}{|l|}{ Oscillatoriales } \\
\hline \multicolumn{5}{|l|}{ Cyanotheceaceae } \\
\hline Cyanothece aeruginosa (Nägeli) Komárek & & & & 2 \\
\hline
\end{tabular}

\section{Borziaceae}

Borzia trilocularis Cohn ex Gomont

\section{Microcoleaceae}

Kamptonema animale (Agardh ex Gomont) Strunecký, Komárek \& Šmarda 2

Kamptonema laetevirens (Crouan \& Crouan ex Gomont) Strunecký, Komárek 2 \& Šmarda

Microcoleus autumnalis (Gomont) Strunecký, Komárek \& Johansen

Microcoleus vaginatus (Vaucher) Gomont ex Gomont

$\begin{array}{lll}3 & 3 & 2\end{array}$

Microcoleus sp. 1

$\begin{array}{llll}5 & 3 & 4 & 5\end{array}$


Microcoleus sp. 2

$B o F \quad B r F \quad F S \quad S^{*}$

Microcoleus sp. 3

Oxynema cf. acuminatum(Gomont) Chatchawan, Komárek, Strunecký, Šmarda 2

\& Peerapornpisal

Pseudophormidium hollerbachianum (Elenkin) Anagnostidis

$\begin{array}{llll}4 & 4 & 4 & 6\end{array}$

\section{Oscillatoriaceae}

Lyngbya martensiana Meneghini ex Gomont

Phormidium aerugineo-caeruleum (Gomont) Anagnostidis \& Komárek

Phormidium ambiguum Gomont ex Gomont

2

Phormidium breve (Kützing ex Gomont) Anagnostidis \& Komárek

Phormidium corium Gomont

Phormidium dimorphum Lemmermann

Phormidium cf. jadinianum Gomont

$\begin{array}{llll} & & 2 & 2 \\ 4 & 2 & 3 & 4 \\ 3 & 1 & 4 & 2 \\ 2 & 3 & 3 & 3 \\ 3 & & & 3 \\ 3 & & & \\ 2 & & & \\ 2 & & & \\ 2 & & \end{array}$

Phormidium cf. retzii (Agardh) Gomont ex Gomont

Phormidium tergestinum (Kützing) Anagnostidis \& Komárek 2

Phormidium uncinatum (Agardh) Gomont $\quad 2$

Phormidium sp. $1 \quad 2$

Phormidium sp. 2

\section{Gomontiellaceae}

Hormoscilla pringsheimii Anagnostidis \& Komárek

Nostocales

\section{Scytonemataceae}

Scytonema $\mathrm{sp}$.

\section{Rivulariaceae}

Roholtiella bashkiriorum Gaysina \& Bohunická

Roholtiella edaphica Bohunická \& Lukešová

Roholtiella fluviatilis Johansen \& Gaysina

\section{Nostocaceae}

Cylindrospermum majus Kützing ex Bornet \& Flahault

$\begin{array}{lll}3 & 3 & 4\end{array}$

Cylindrospermum $\mathrm{sp}$.

Desmonostoc cf. muscorum (Agardh ex Bornet \& Flahault) Hrouzek \& Ventura

Nostoc cf. calcicola Brébisson ex Bornet \& Flahault

$\begin{array}{lll}2 & 1 & 4\end{array}$

Nostoc cf. commune Vaucher ex Bornet \& Flahault

$3 \quad 3 \quad 2$

Nostoc cf. ellipsosporum Rabenhorst

Nostoc cf. microscopicum Carmichael ex Bornet \& Flahault

2

Nostoc cf. punctiforme Kützing (Hariot)

$\begin{array}{lll}3 & 2 & 1\end{array}$

Trichormus variabilis (Kützing ex Bornet \& Flahault) Komárek \& Anagnostidis $\quad 4 \quad 3 \quad 4$

Trichormus sp.

\begin{tabular}{lcccc}
\hline Number of samples & 17 & 21 & 29 & 18 \\
\hline Number of species & 39 & 18 & 29 & 24 \\
\hline Minimum/maximum species per site & $0 / 13$ & $0 / 9$ & $0 / 14$ & $1 / 10$ \\
\hline
\end{tabular}


et al., 1988):

Descriptions of the studied zones are as follows (taken from Alekseev

1. Boreal forest zone - characterized by humid conditions and prevalence of coniferous trees Picea obovata Ledeb. and Abies sibirica Ledeb., with rare deciduous trees Tilia cordata Mill., Acer platanoides L., Ulmus glabra Huds. and Quercus robur L. Sample sites were in Beloretskiy region and near Pavlovka village (Fig. 1, sites 1 and 2). Soils in sites in the Beloretskiy region are podzolized chernozem, near Pavlovka village - dark gray forest and floodplain soils (Table 2) (Khaziyev, 2012).

2. Broad-leaved forest zone - contains mixed forests of Quercus robur L., Tilia cordata Mill., and Ulmus glabra Huds. This zone is one of the most damaged parts of Bashkortostan as a result of anthropogenic influence. Samples were taken near Bakaly, Iglino, and Krasnousolskiy villages (Fig. 1, sites 3, 4, 5). All samples in this zone were from sites with podzolized chernozem (Table 2) (Khaziyev, 2012).

3. Forest-steppe zone - combination of forest and steppe communities. Most of the territory is characterized by forest-steppe of European type with broad-leaved trees like Quercus robur L., Tilia cordata Mill., and Acer platanoides L. In only the north-eastern part of this zone (site 8), forests are dominated by Betula pendula Roth, Betula pubescens Ehrh. and Pinus sylvestris L. Samples were taken near Dyurtyuli town, and Tolbazy, Bolsheustikinskoye, and Georgievka villages (Fig. 1, sites 6, 7, 8, 9). Soils in sample sites near Dyurtyuli and Tolbazy were leached chernozems, Bolsheustikinskoye - gray forest soils and floodplain soils (Table 2) (Khaziyev, 2012).

4. Steppe zone - originally, the basis of the vegetation in this zone within Bashkiria were steppes with dominance of Stipa pulcherrima K.Koch in the north, Stipa lessingiana Trin. \& Rupr. in the south, and Stipa zalesskii Wilensky in the middle part. Currently, steppes are almost completely destroyed by human activities. Small areas of the forest vegetation remain situated in more humid conditions in the valleys, on the slopes of ravines and floodplains. Samples were taken near Sibay town, Yangelskiy village, and Arkaim monument (Fig. 1, sites 10, 11, 12). Soils in study sited near Sibay were characterized as south chernozem, near Yangelskiy and Arkaim as ordinary chernozem (Table 2) (Khaziyev, 2012; Prikhod'ko et al. (2012).

\section{Strain isolation and culture observation}

For isolation of pure strains, enrichment cultures on solidified BBM medium (Bischoff \& Bold, 1963; Kostikov et al., 2001) and the dilution method of Bohunická et al. (2015) were used. For obtaining additional information about cyanobacterial biodiversity, direct observation of cyanobacteria on cover slips was also used (Lund, 1945; Hoffmann et al., 2007). For this purpose, about 15-20 grams of soil were placed into a Petri dish and moisturized until $80 \%$ of full moisture capacity. The next day, four sterilized cover slips were put onto the surface of the soil and slightly pressed. After that between soil surface and cover slip small wet chambers arose, where cyanobacteria started to grow after 2-4 weeks of cultivation. During strain isolation, petri dishes with soil placed onto agar solidified media (1.5\%) were incubated at room temperature on an illuminated shelf with $12 \mathrm{~h}: 12 \mathrm{~h}$ light:dark regime. Pure cultures in tubes on 1.5\% agar-solidified media slants were then stored at $4{ }^{\circ} \mathrm{C}$ in a refrigerator with transparent door (natural daylight regime). 


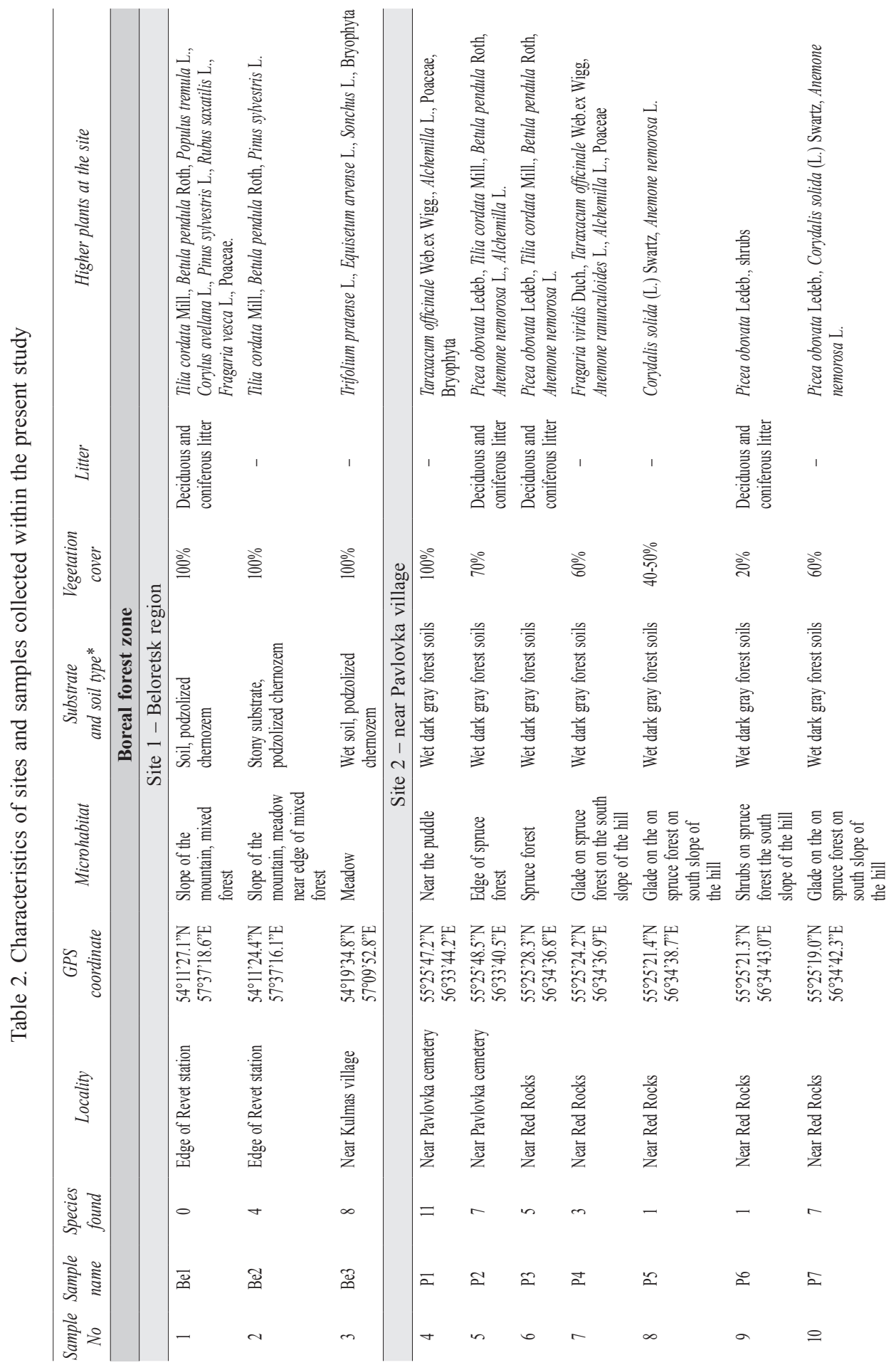




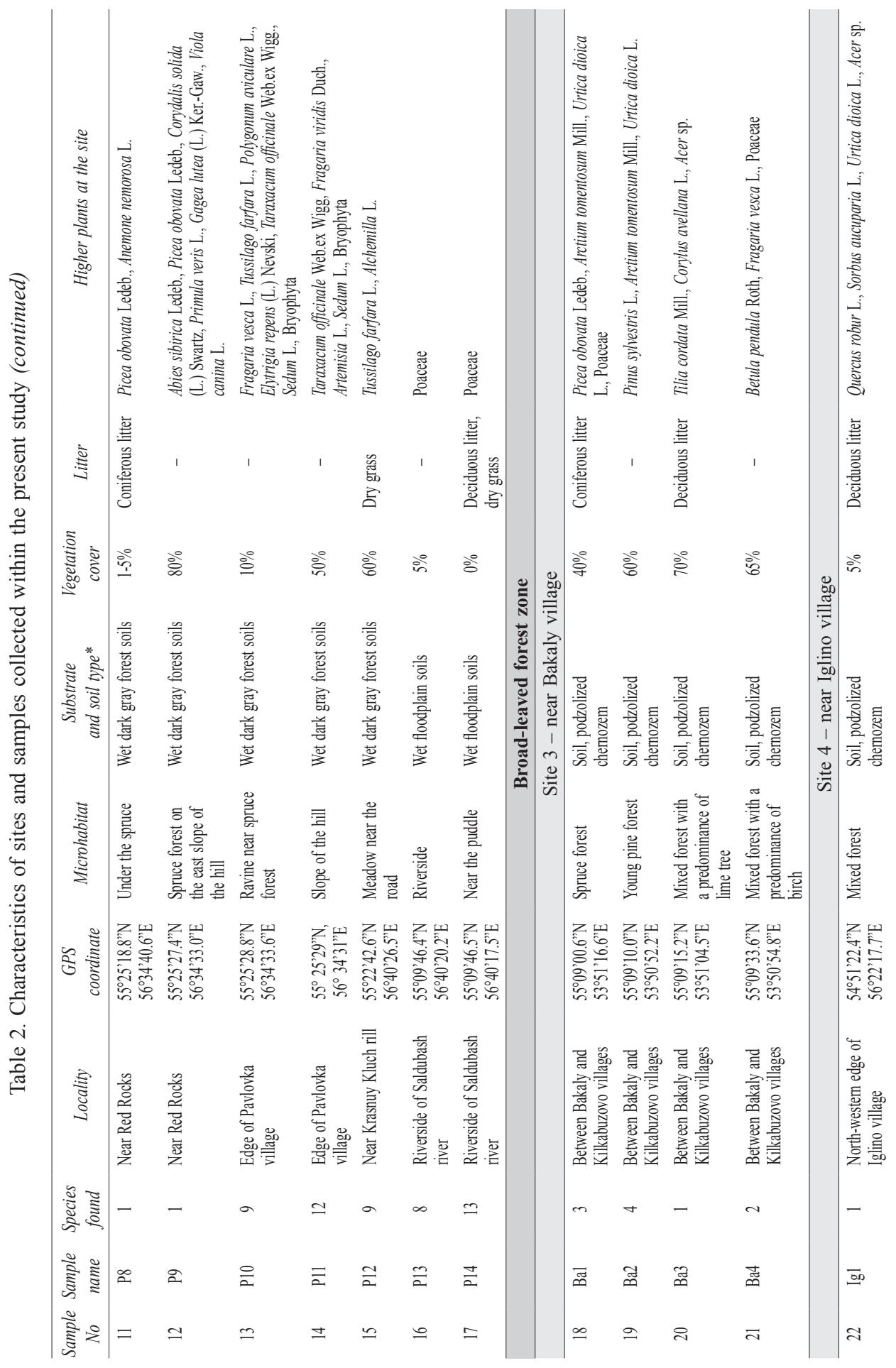




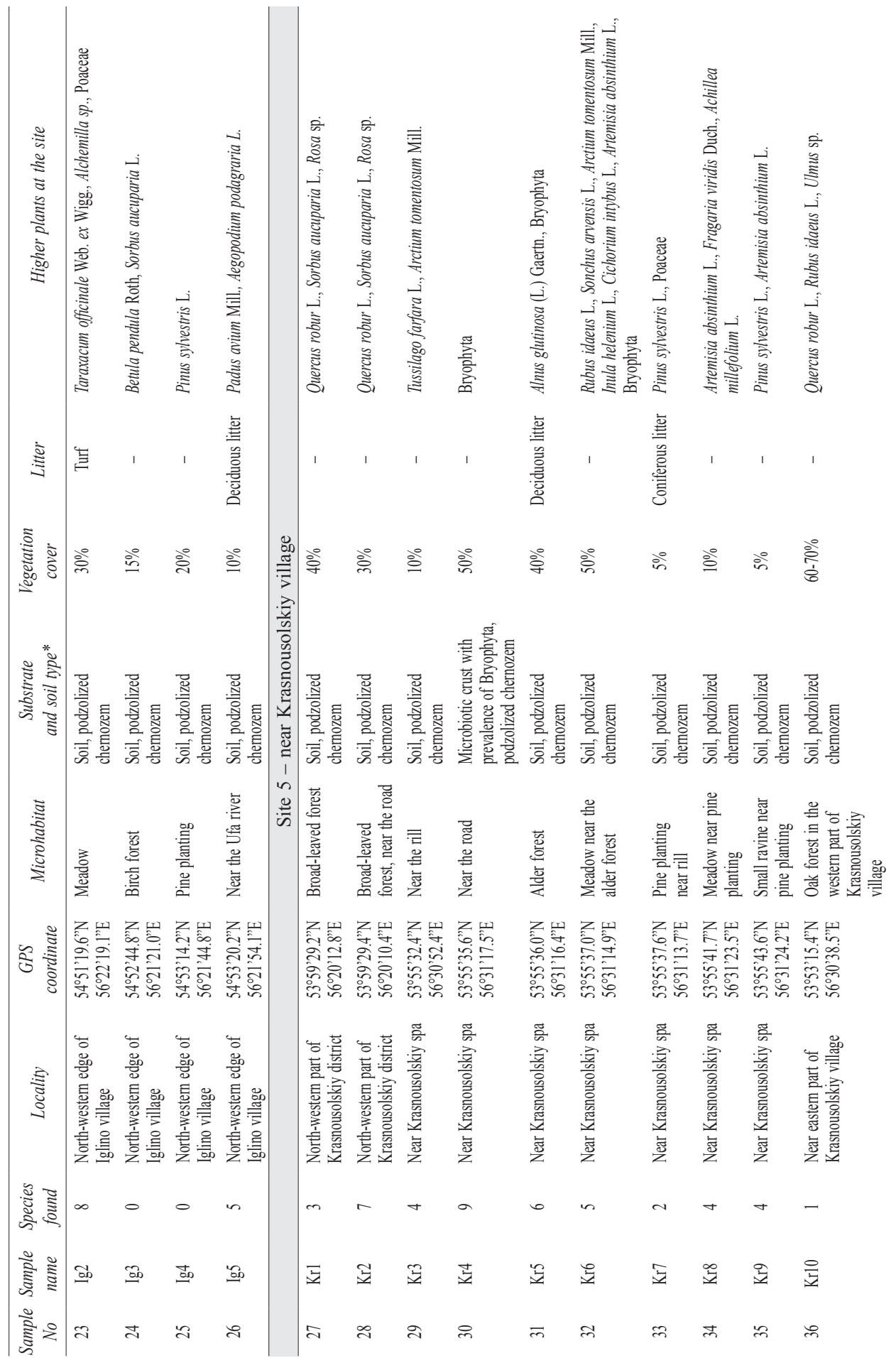




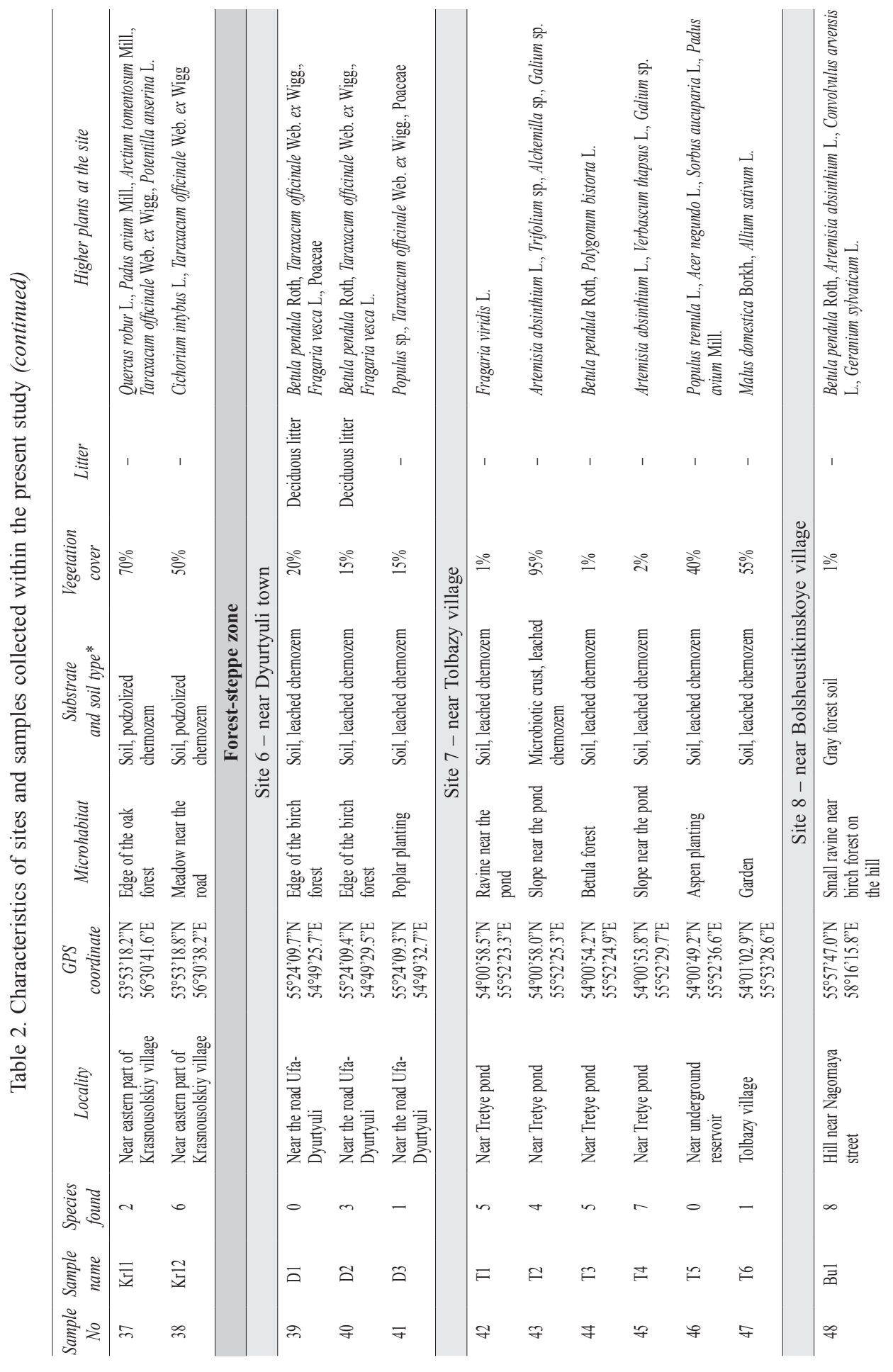




\begin{tabular}{|c|c|c|c|c|c|c|c|c|c|c|c|c|}
\hline 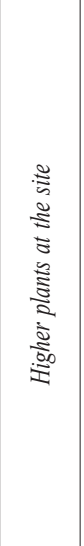 & 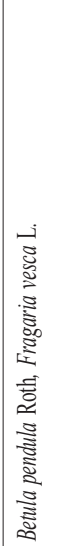 & 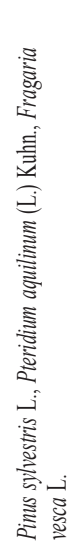 & 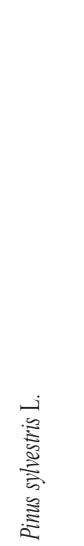 & 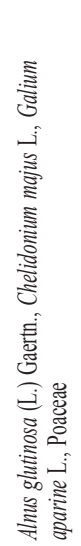 & 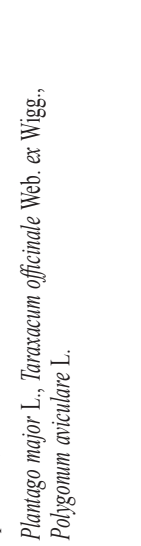 & 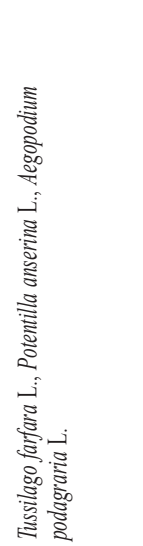 & 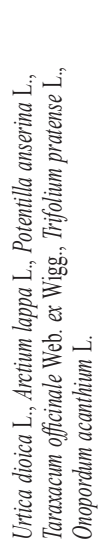 & 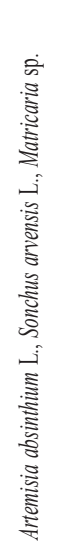 & 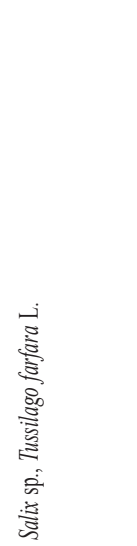 & 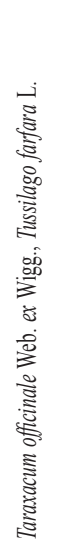 & 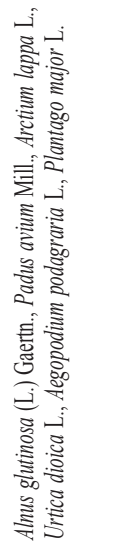 & 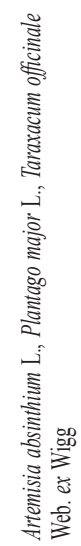 \\
\hline$\stackrel{\bar{\Xi}}{\Xi}$ & 1 & 1 & 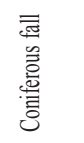 & 1 & 1 & 1 & 1 & 1 & 1 & 声 & 1 & 1 \\
\hline 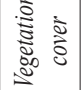 & 亏े & 今े & $\stackrel{\circ}{\circ}$ & $\therefore$ & in & ळे & தి & ڤ్̀ & ळे & ळे & ळे & $\grave{\varrho}$ \\
\hline 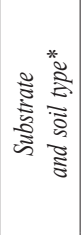 & 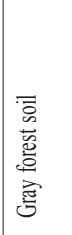 & 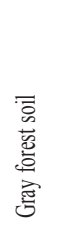 & 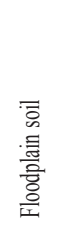 & 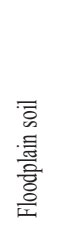 & 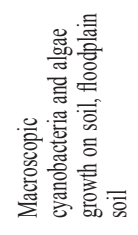 & 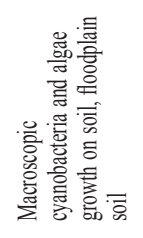 & 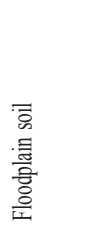 & 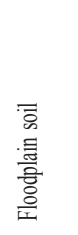 & 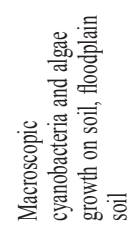 & 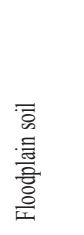 & 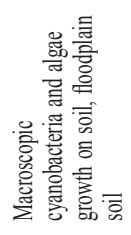 & 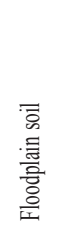 \\
\hline 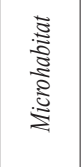 & 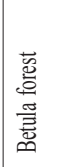 & 总 & 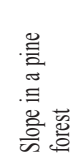 & 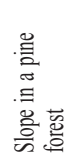 & 靑 & 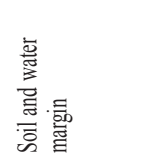 & 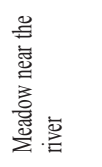 & 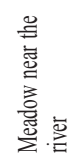 & 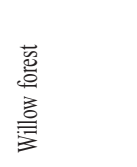 & 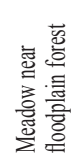 & 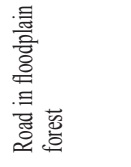 & 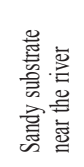 \\
\hline 芯 & 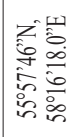 & 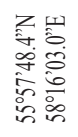 & 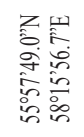 & 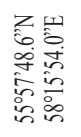 & 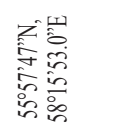 & 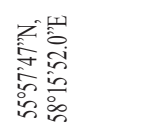 & 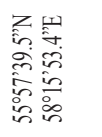 & 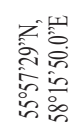 & 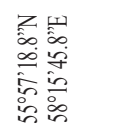 & 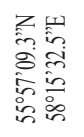 & 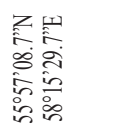 & 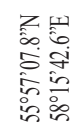 \\
\hline $\begin{array}{l}\text { 胥 } \\
\text { 马े }\end{array}$ & 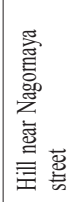 & 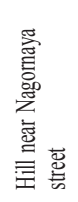 & 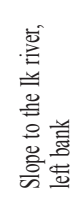 & 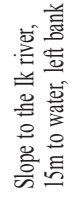 & 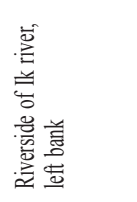 & 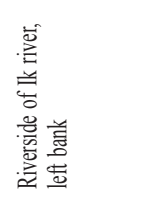 & 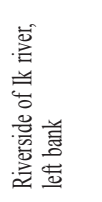 & 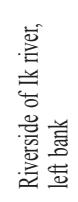 & 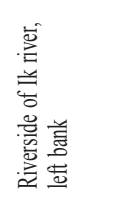 & 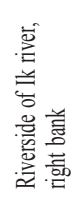 & 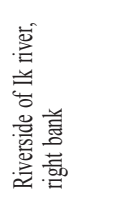 & 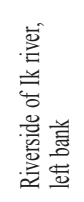 \\
\hline 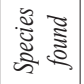 & in & - & $\sigma$ & 6 & $m$ & m & m & $a$ & $r$ & $a$ & $\Xi$ & in \\
\hline 胥 & ๓ี & 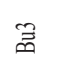 & 㔛 & $\cong$ & 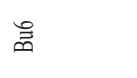 & ఐ & 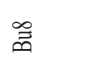 & ఏે & 号 & $\overline{\bar{\emptyset}}$ & $\stackrel{\beth}{\Xi}$ & $\stackrel{\widetilde{\Xi}}{\bar{m}}$ \\
\hline 를 & f & 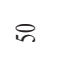 & $\vec{n}$ & $\approx$ & $\approx$ & 怘 & $\therefore$ & 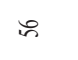 & $\tilde{n}$ & $\infty$ & on & 8 \\
\hline
\end{tabular}




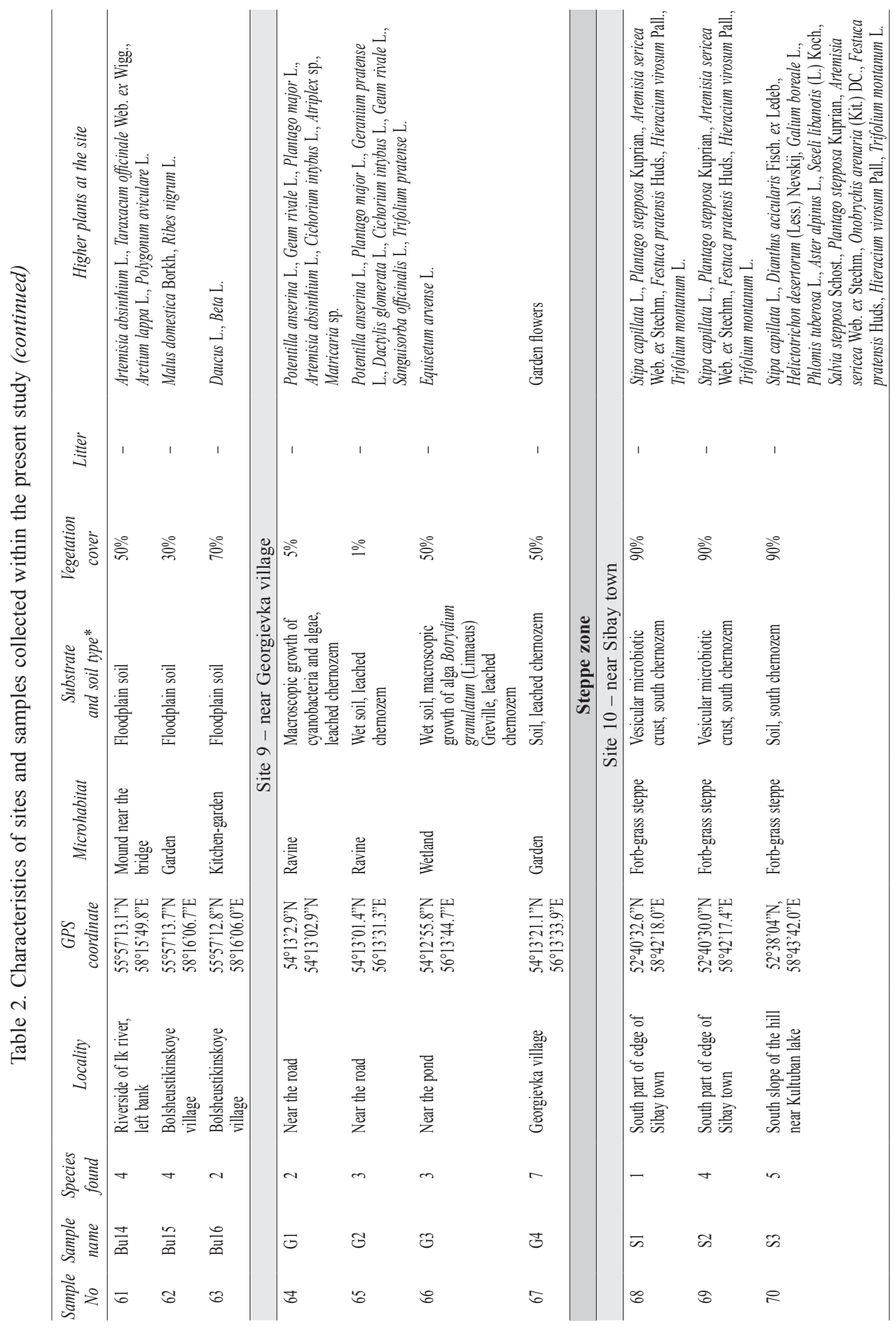




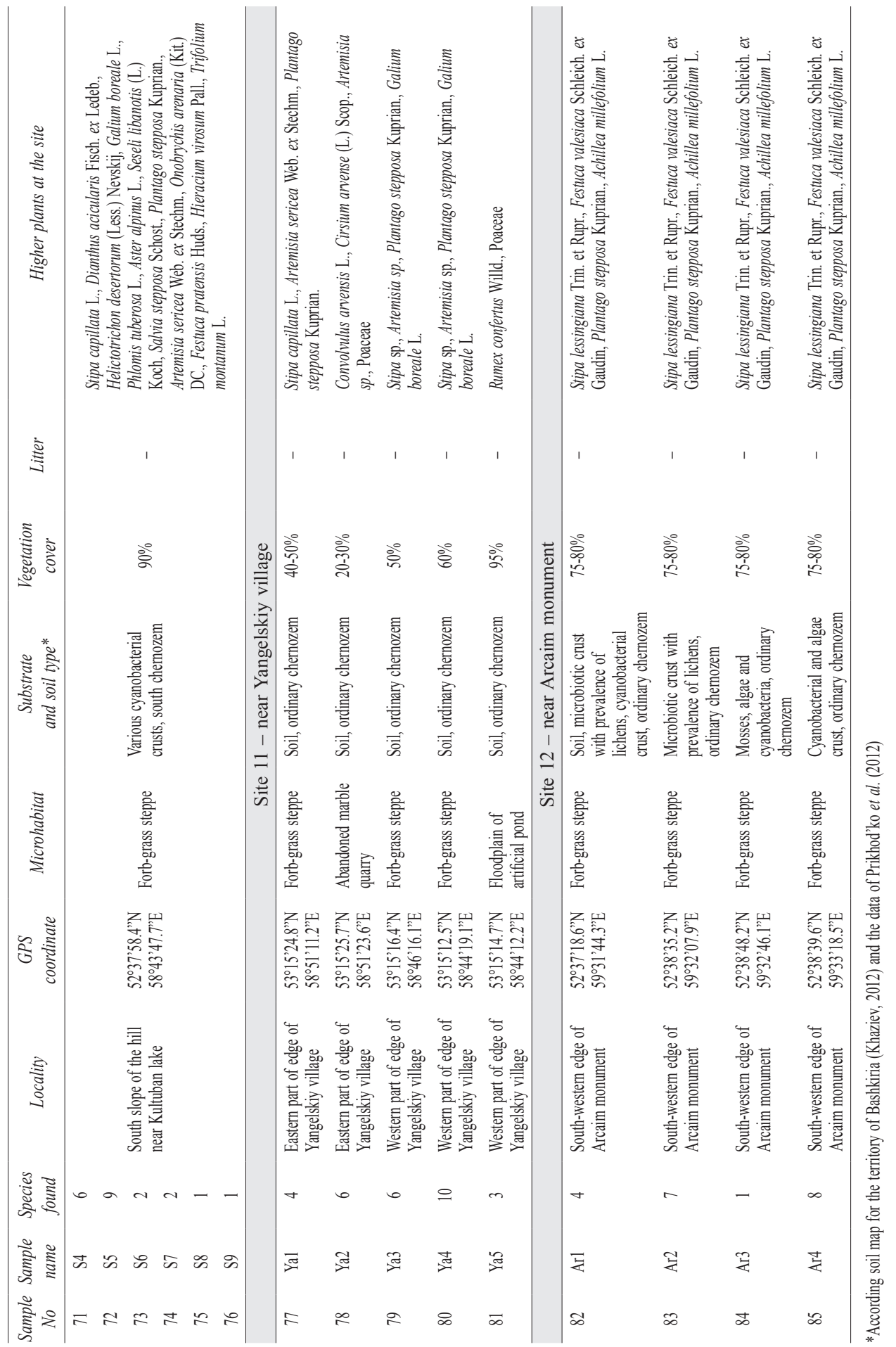


Observations of cyanobacteria were conducted using a Zeiss Axio Imager A2 microscope with DIC optics and Axio Vision 4.9 visualization system. Microphotographs were taken with an Axio Cam MRc camera on magnifications $\times 400$ and $\times 1000$. For identification of the taxa and classification, the relevant reference sources were used (Anagnostidis \& Komárek, 1988; Guiry \& Guiry, 2016, Komárek \& Anagnostidis, 1999, 2005; Komárek, 2013; Komárek et al., 2014). Typical morphological features of filamentous taxa, such as filament, trichome, and cell dimensions, sheath color, cell color, heterocyte and akinete dimensions, length of apical cells in filamentous taxa, degree of constriction at crosswalls, special features associated with end cells and necridia, filament polarity, tapering, and type of branching, when present, were observed and measured for each taxon and the proper identification was supplemented with the knowledge on the ecological data. For coccoid taxa, planes of cell division, cell shape, degree of lamellation of the cellular and colonial mucilage, sheath and cell color, and dimensions and shape of cells were used for identification.

The species list was created based on frequency of occurrence according Braun-Blanquet scale with modifications: $1=0.1-5 \% ; 2=6-10 \% ; 3=11-20 \%$; $4=21-40 \% ; 5=41-60 \% ; 6=61-80 \% ; 7=81-100 \%$ (Braun-Blanquet, 1951). Frequencies represent abundances in samples resulting from direct observation and from counting of cultures.

\section{Statistical analysis}

Using the R package 'vegan' (Oksanen et al., 2017), a principle component analysis (PCA, Jolliffe, 1986) was performed to characterize compositional variation in soil cyanobacterial community data, using the combined data for each of the 12 sites. Species data were Hellinger transformed prior execution of the ordination. This transformation linearizes species data and alleviates the double zero problem, thereby allows analysis via Euclidean-based ordination methods, such as PCA (Legendre \& Gallagher, 2001). Environmental factors were fitted onto the ordination using 'envfit' function, the goodness of fit was assessed using a permutation test $(n=999)$. All statistical analyses were performed in R software, version 3.4.0 (R Core Team, 2017).

\section{RESULTS}

Fifty-six cyanobacteria were identified. The total number of species was highest in the boreal-forest zone (39) and notably lower in the other zones (18, 29, and 24 for broad-leaved forest, forest steppe and steppe regions, respectively). Maximum species per site was higher in forest-steppe and boreal forests, and lower in steppes and broad-leaved forests (Tables 1,2). Descriptions of all species encountered (Table 3) as well as images of most taxa (Figs 2-57) are presented so that evaluation of the taxonomy adopted in the study is possible.

Several species of cyanobacteria were detected in all studied zones: Leptolyngbya voronichiniana (Fig. 10), Leptolyngbya foveolarum (Fig. 3), cf. Trichocoleus hospitus (Fig. 14), Pseudophormidium hollerbachianum (Fig. 29), Nostoc cf. punctiforme (Fig. 55), Microcoleus vaginatus (Fig. 24), Phormidium breve (Fig. 32), Phormidium dimorphum (Fig. 34), Phormidium corium (Fig. 33), and Leptolyngbya cf. tenuis (Fig. 7) (Tables 2, 3). Phormidium, Leptolyngbya and Nostoc (including Desmonostoc, Figs 50-55) were the most abundant genera with 11,8 and 6 species respectively. 


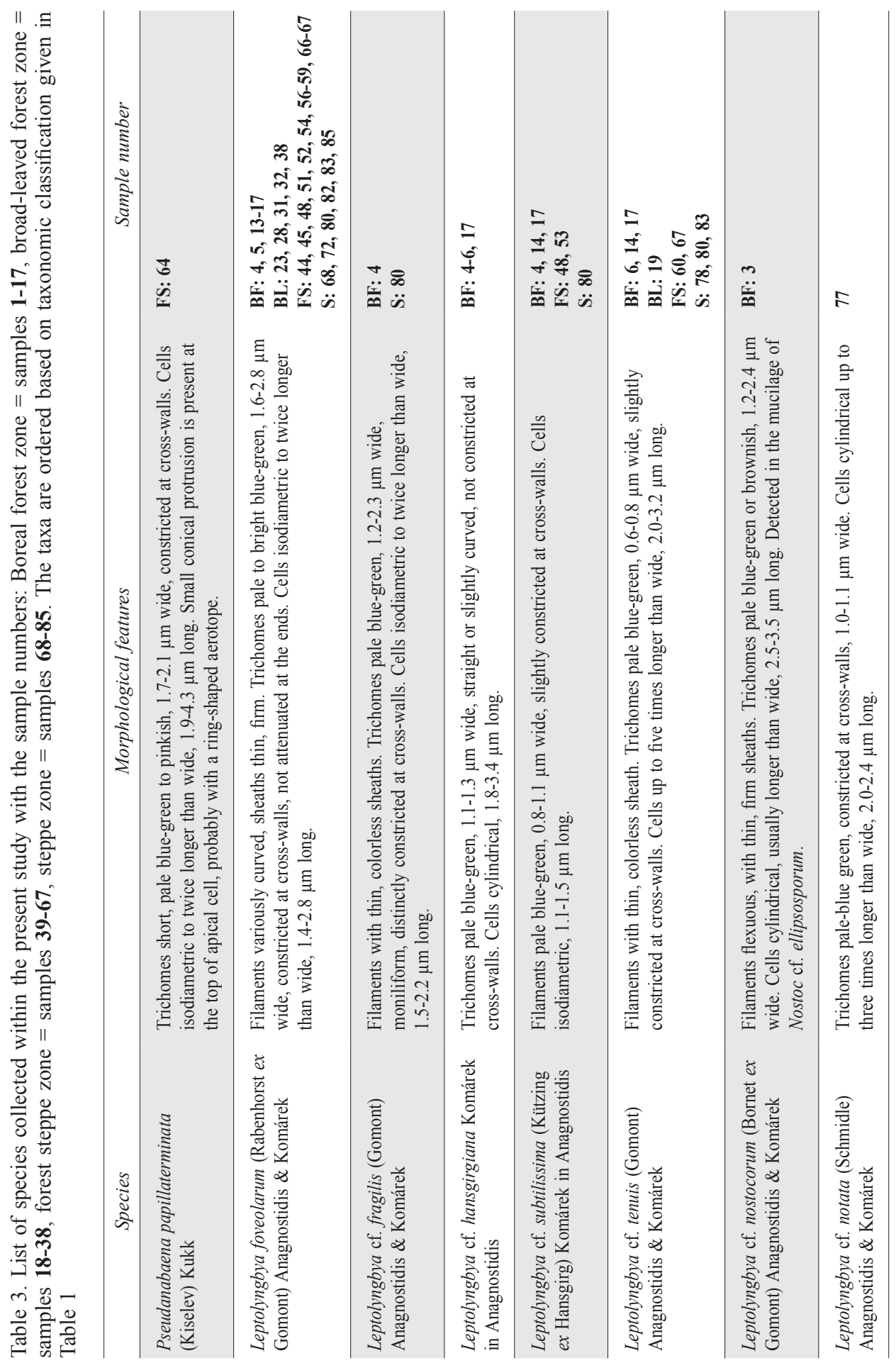




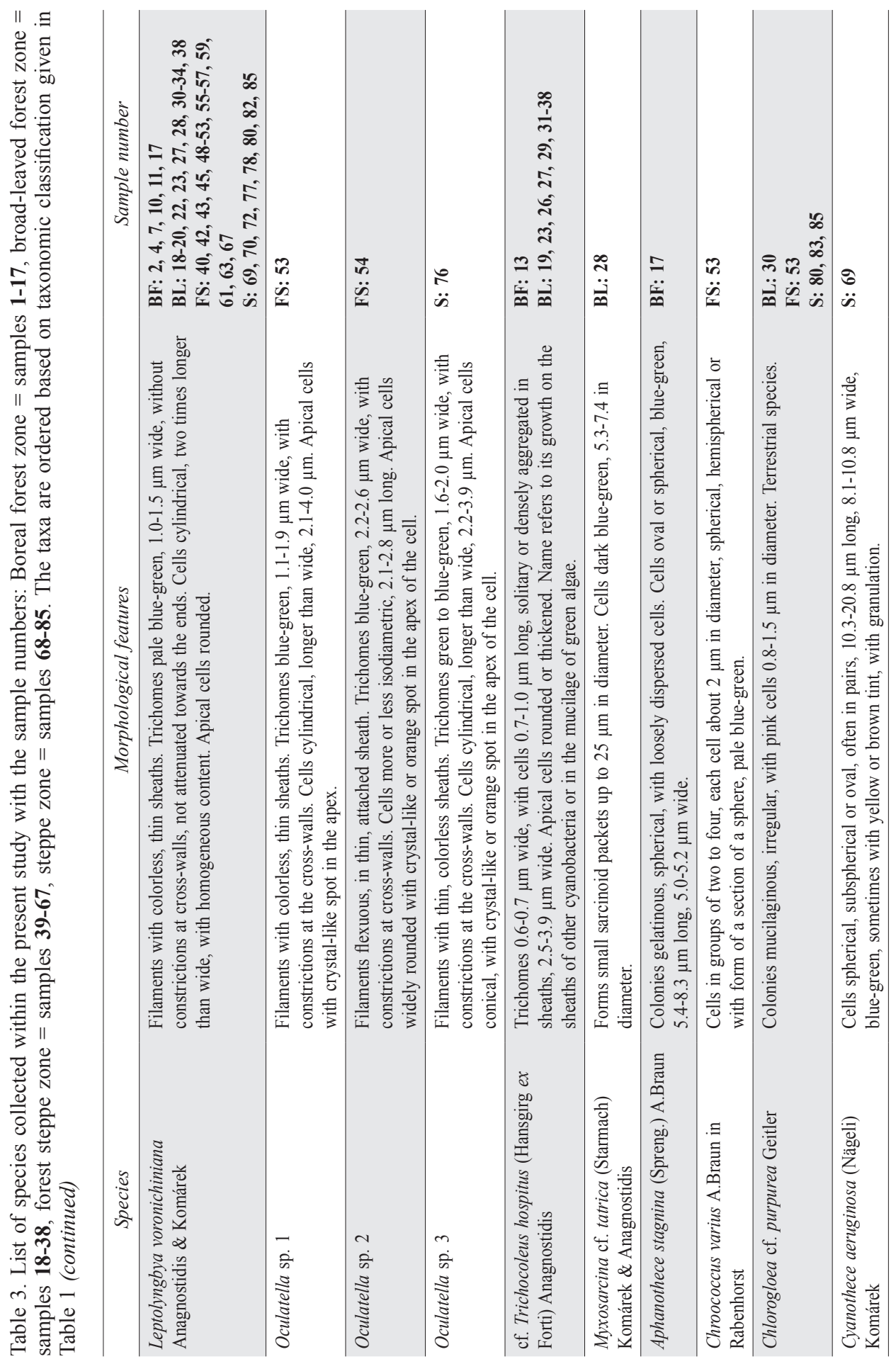




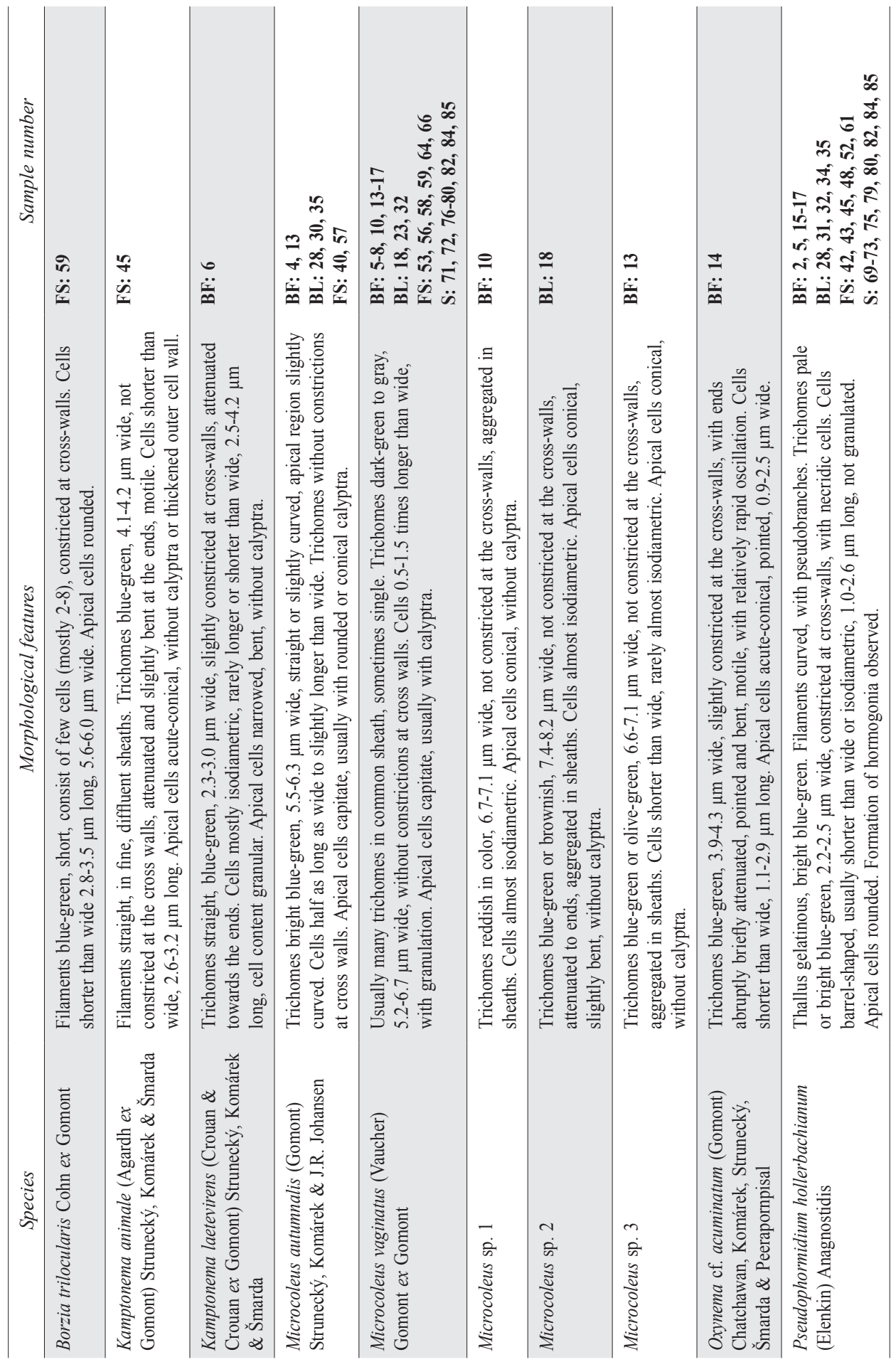




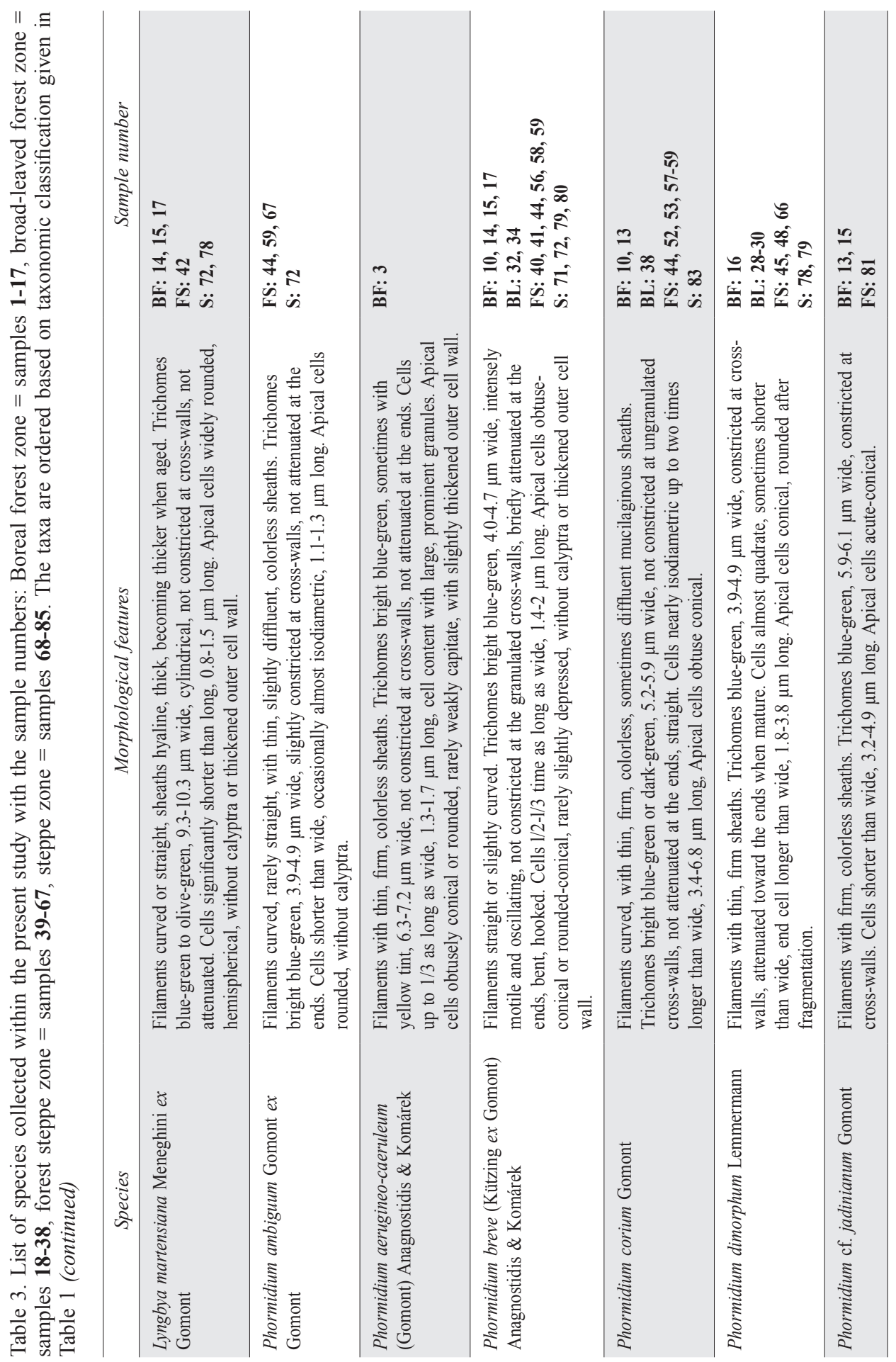




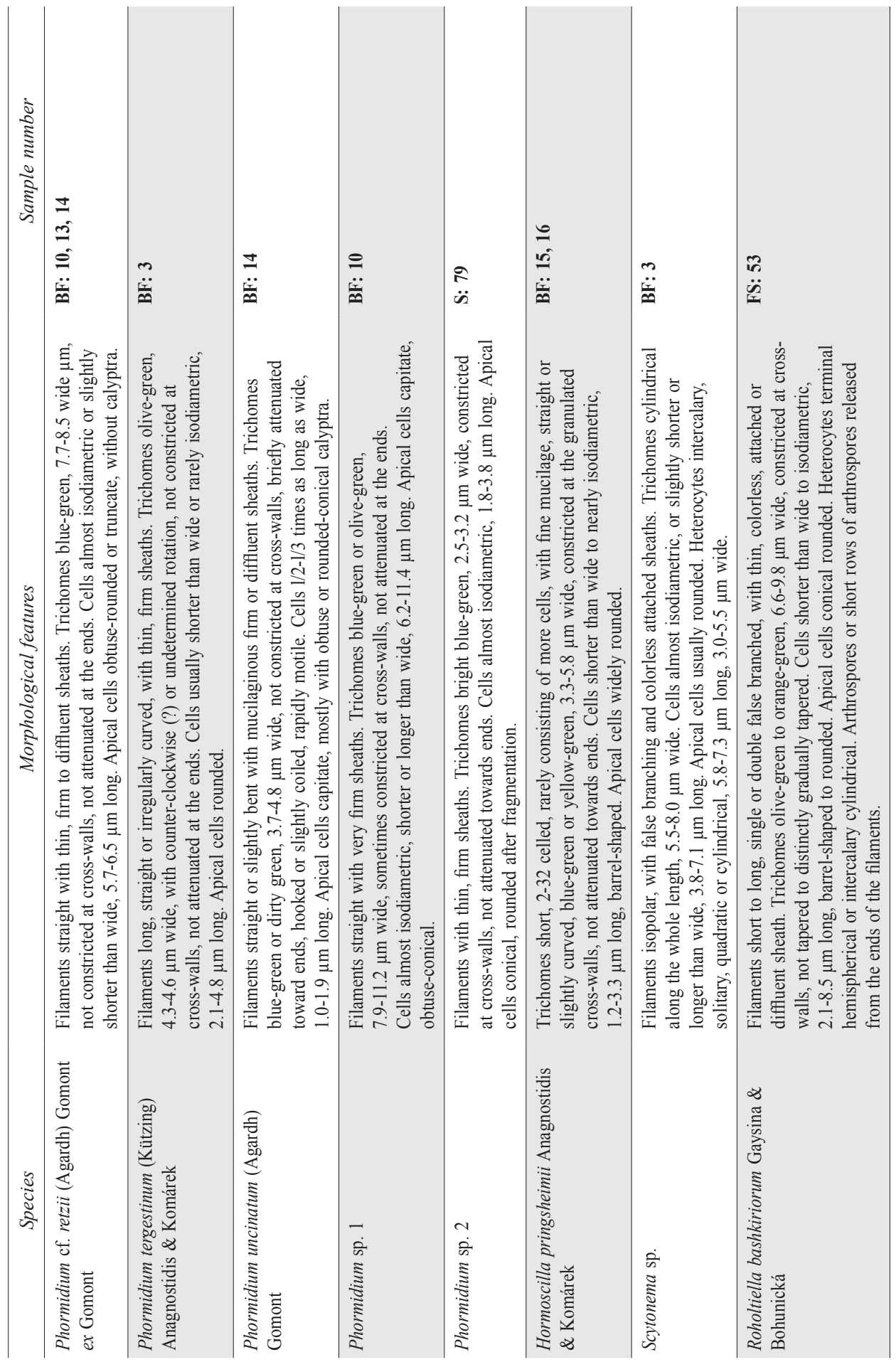




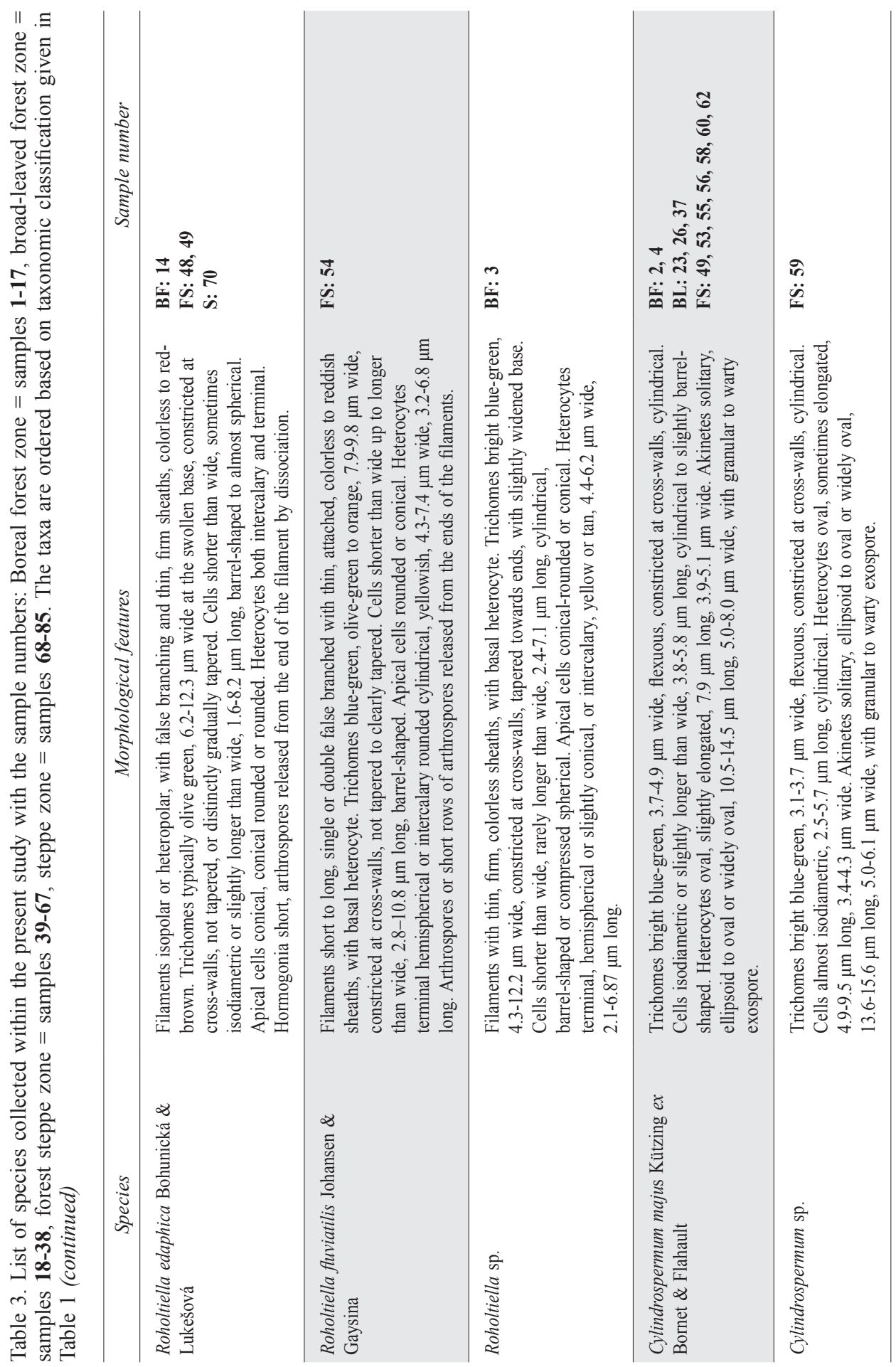




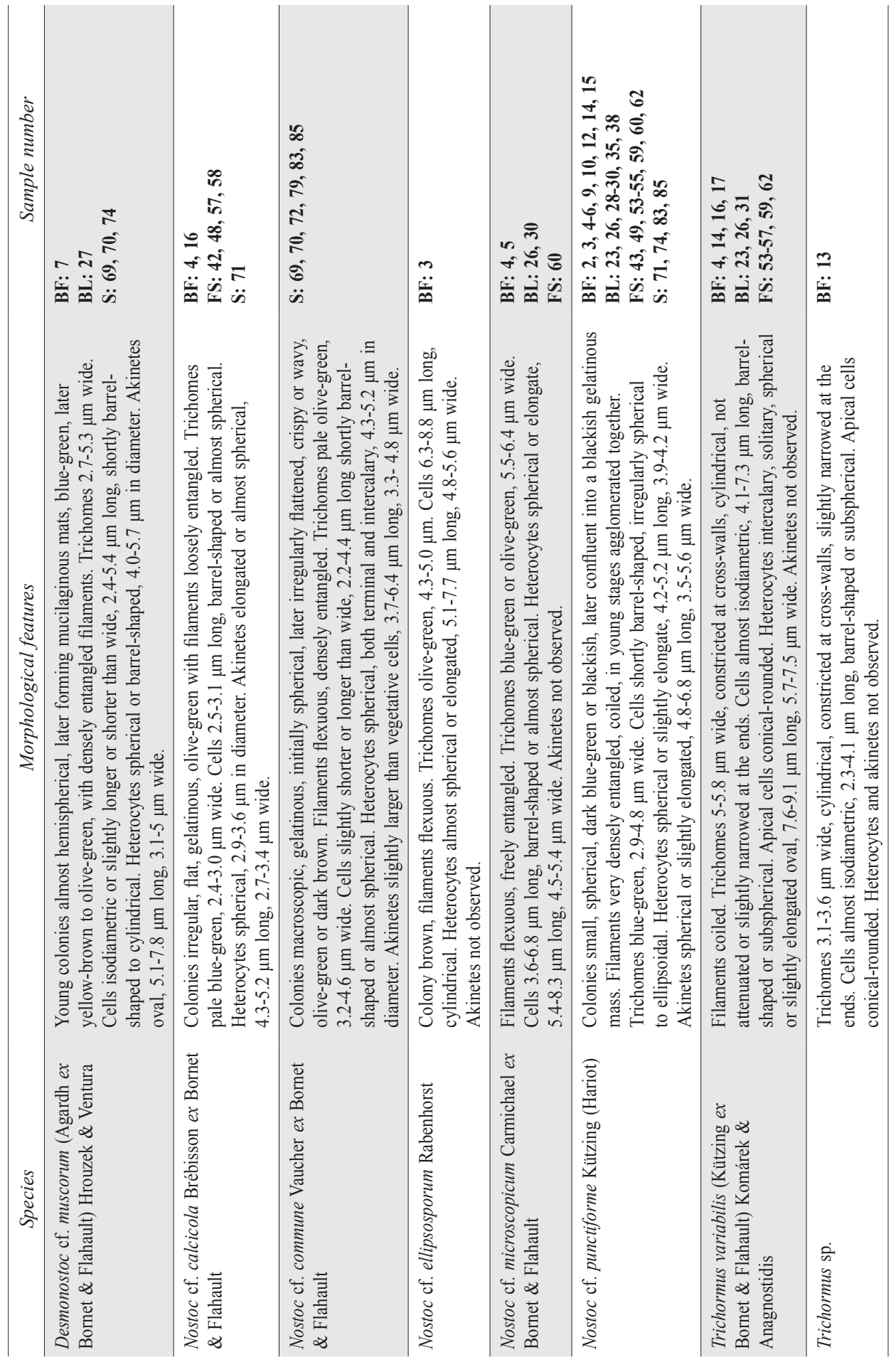




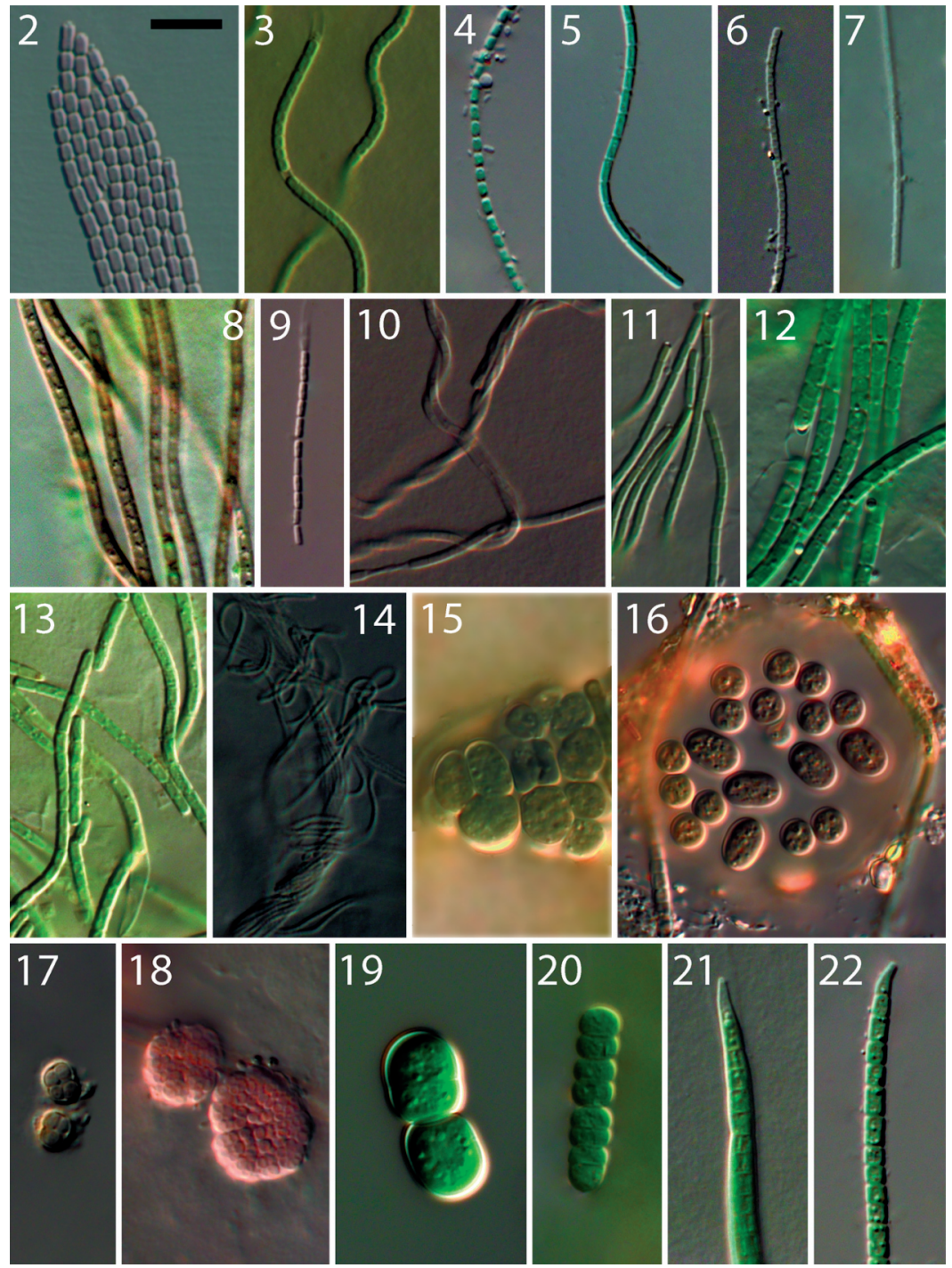

Figs 2-22. Terrestrial cyanobacteria of the South Ural region: 2. Pseudanabaena papillaterminata (Kiselev) Kukk, 3. Leptolyngbya foveolarum (Rabenhorst ex Gomont) Anagnostidis \& Komárek, 4. Leptolyngbya cf. fragilis (Gomont) Anagnostidis \& Komárek, 5. Leptolyngbya cf. hansgirgiana Komárek in Anagnostidis, 6. Leptolyngbya cf. subtilissima (Kützing ex Hansgirg) Komárek in Anagnostidis, 7. Leptolyngbya cf. tenuis (Gomont) Anagnostidis \& Komárek, 8. Leptolyngbya cf. nostocorum (Bornet ex Gomont) Anagnostidis \& Komárek, 9. Leptolyngbya cf. notata (Schmidle) Anagnostidis et Komárek, 10. Leptolyngbya voronichiniana Anagnostidis \& Komárek, 11. Oculatella sp. 1, 12. Oculatella sp. 2, 13. Oculatella sp. 3, 14. cf. Trichocoleus hospitus (Hansgirg ex Gomont) Anagnostidis, 15. Myxosarcina cf. tatrica (Starmach) Komárek \& Anagnostidis, 16. Aphanothece stagnina (Spreng.) A.Braun, 17. Chroococcus varius A. Braun in Rabenhorst, 18. Chlorogloea cf. purpurea Geitler, 19. Cyanothece aeruginosa (Nägeli) Komárek, 20. Borzia trilocularis Cohn ex Gomont, 21. Kamptonema animale (C.Agardh ex Gomont) Strunecký, Komárek \& Šmarda, 22. Kamptonema laetevirens (Crouan \& Crouan ex Gomont) Strunecký, Komárek \& Šmarda. Scale bar $=10 \mu \mathrm{m}$, applies to all figures. 


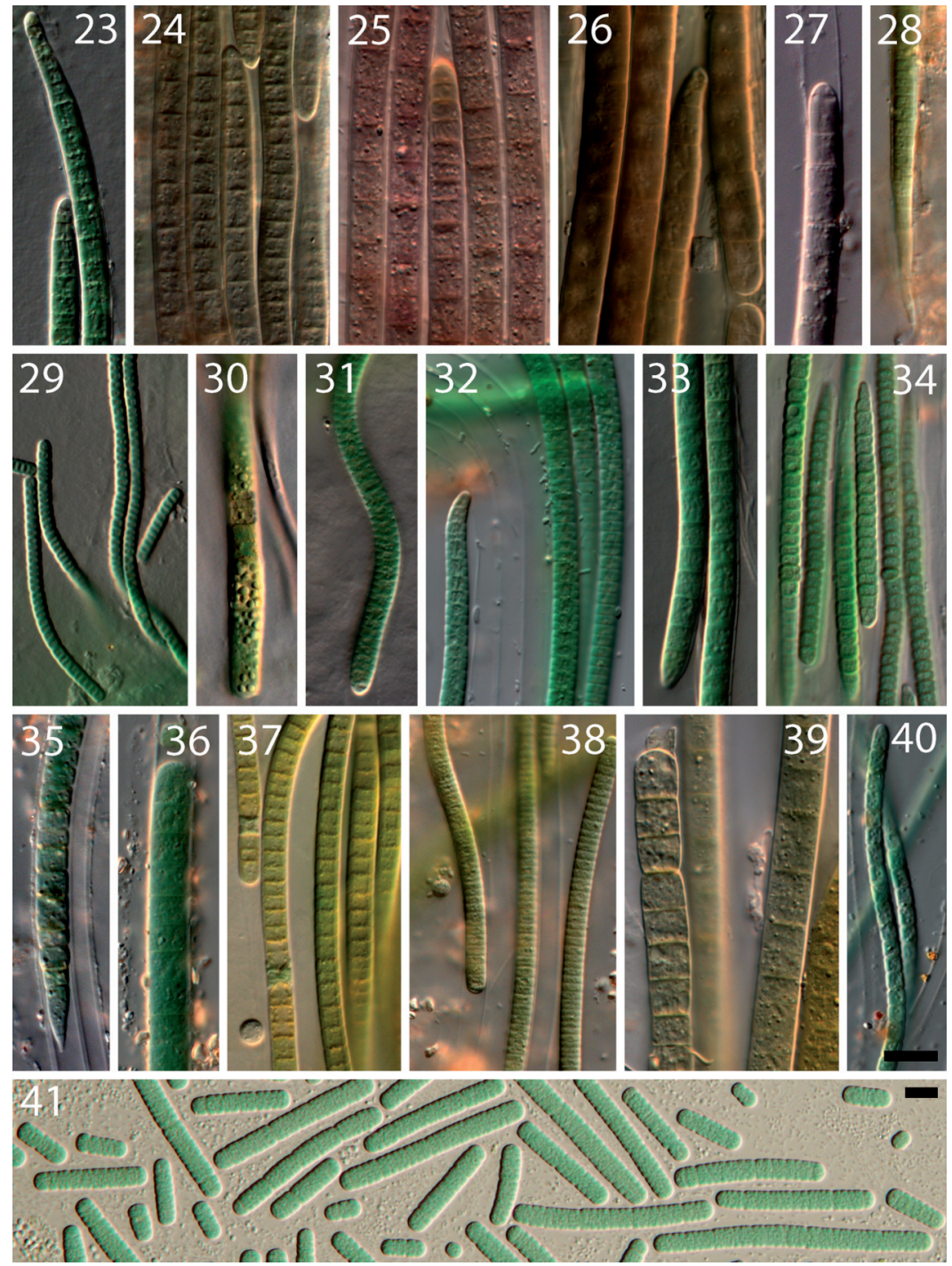

Figs 23-41. Terrestrial cyanobacteria of the South Ural region: 23. Microcoleus autumnalis (Gomont) Strunecký, Komárek \& Johansen, 24. Microcoleus vaginatus (Vaucher) Gomont ex Gomont, 25. Microcoleus sp. 1, 26. Microcoleus sp. 2, 27. Microcoleus sp. 3, 28. Oxynema cf. acuminatum (Gomont) Chatchawan, Komárek, Strunecký, Šmarda \& Peerapornpisal, 29. Pseudophormidium hollerbachianum (Elenkin) Anagnostidis, 30. Phormidium aerugineo-caeruleum (Gomont) Anagnostidis \& Komárek, 31. Phormidium ambiguum Gomont ex Gomont, 32. Phormidium breve (Kützing ex Gomont) Anagnostidis \& Komárek, 33. Phormidium corium Gomont, 34. Phormidium dimorphum Lemmermann, 35. Phormidium cf. jadinianum Gomont, 36. Phormidium cf. retzii (Agardh) Gomont ex Gomont, 37. Phormidium tergestinum (Kützing) Anagnostidis \& Komárek, 38. Phormidium uncinatum (Agardh) Gomont, 39. Phormidium sp. 1, 40. Phormidium sp. 2, 41. Hormoscilla pringsheimii Anagnostidis \& Komárek. Scale bars $=10 \mu \mathrm{m}$, for figures 23-40 the bar is placed in figure 40 . 

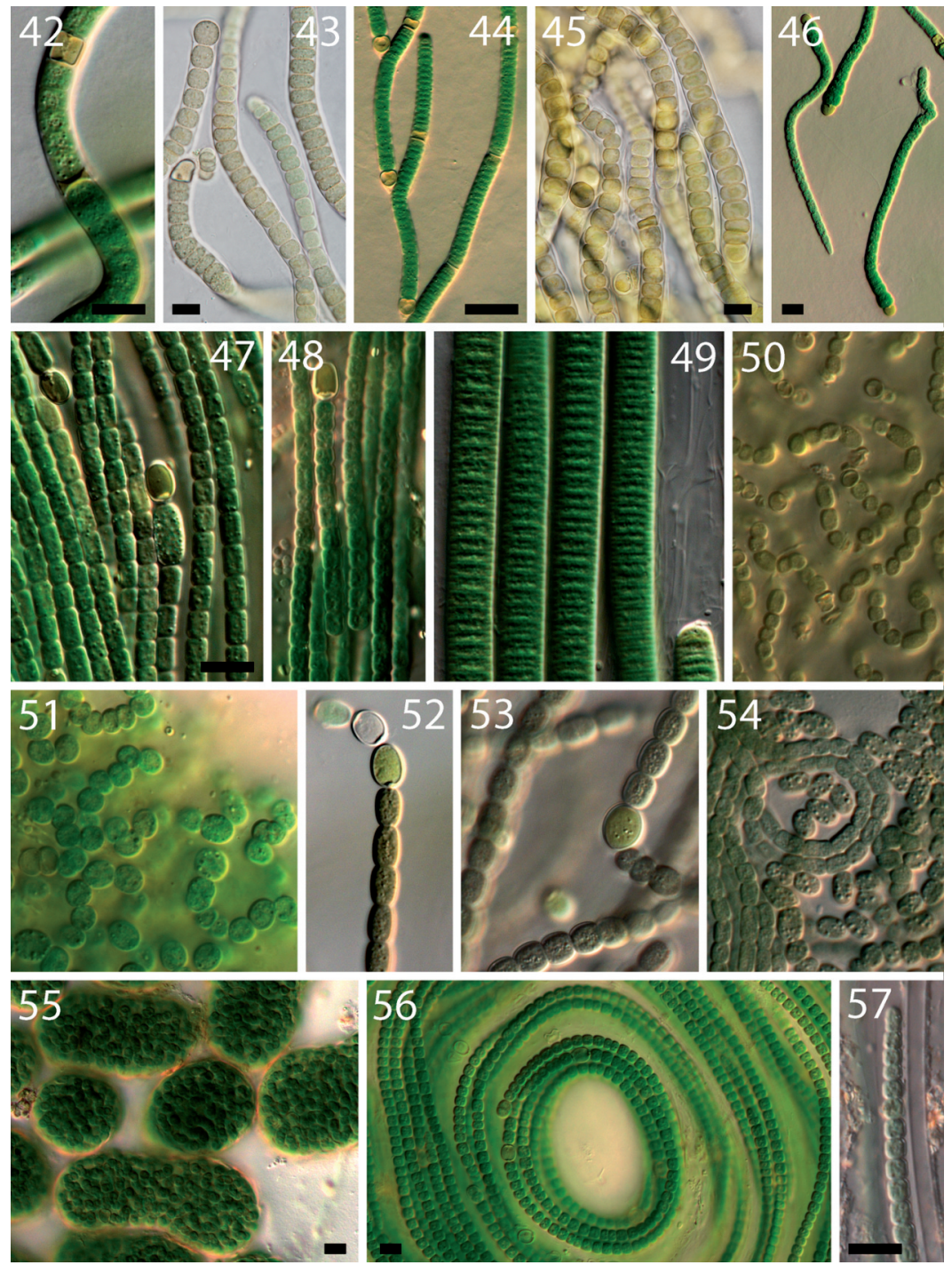

Figs 42-57. Terrestrial cyanobacteria of the South Ural region: 42. Scytonema sp., 43. Roholtiella bashkiriorum Gaysina \& Bohunická, 44. Roholtiella edaphica Bohunická \& Lukešová, 45. Roholtiella fluviatilis Johansen \& Gaysina, 46. Roholtiella sp., 47. Cylindrospermum majus Kützing ex Bornet \& Flahault, 48. Cylindrospermum sp., 49. Lyngbya martensiana Meneghini ex Gomont, 50. Nostoc cf. calcicola Brébisson ex Bornet \& Flahault, 51. Nostoc cf. commune Vaucher ex Bornet \& Flahault, 52. Nostoc cf. ellipsosporum Rabenhorst, 53. Nostoc cf. microscopicum Carmichael ex Bornet \& Flahault, 54. Desmonostoc cf. muscorum C.Agardh, 55. Nostoc cf. punctiforme Kützing (Hariot), 56. Trichormus variabilis (Kützing ex Bornet \& Flahault) Komárek \& Anagnostidis, 57. Trichormus sp. Scale bars $=10 \mu \mathrm{m}$, for figures $47-54$ the bar is placed in figure 47 . 
Many species were found only in the boreal-forest zone: Aphanothece stagnina (Fig. 16), Hormoscilla pringsheimii (Fig. 41), Leptolyngbya cf. hansgirgiana (Fig. 5), Leptolyngbya cf. nostocorum (Fig. 8), Kamptonema animale (Fig. 21), Kamptonema laetevirens (Fig. 22), Microcoleus sp. 1 (Fig. 25), Microcoleus sp. 3 (Fig. 27), Oxynema cf. acuminatum (Fig. 28), Phormidium aerugineo-caeruleum (Fig. 30), Phormidium cf. retzii (Fig. 36), Phormidium tergestinum (Fig. 37), Phormidium uncinatum (Fig. 38), Phormidium sp. 1 (Fig. 39), Nostoc cf. ellipsosporum (Fig. 52), Scytonema sp. (Fig. 42), Trichormus sp. (Fig. 57) (Tables 2, 3). Lyngbya martensiana was detected in all zones, excluding the broadleaved forest zone; it was most abundant in the boreal forest zone (Fig. 49) (Tables 2, 3).

The broad-leaved forest was characterized by the wide distribution of cf. Trichocoleus hospitus (Tables 2, 3). Myxosarcina cf. tatrica (Fig. 15) and Chroococcus varius (Fig. 17) were also detected only in this type of ecosystem.

Trichormus variabilis (Fig. 56), Cylindrospermum majus (Fig. 47), Microcoleus autumnalis (Fig. 23), and Nostoc cf. microscopicum (Fig. 53) were widely distributed in forest and forest-steppe zones.

Phormidium ambiguum (Fig. 31), was typical for forest-steppe and steppe zones. In the forest-steppe zone, some rare species, like Borzia trilocularis (Fig. 20), and Pseudanabaena papillaterminata (Fig. 2), were detected. Cylindrospermum sp. was also found in forest-steppe (Fig. 48) (Tables 1, 2, 3).

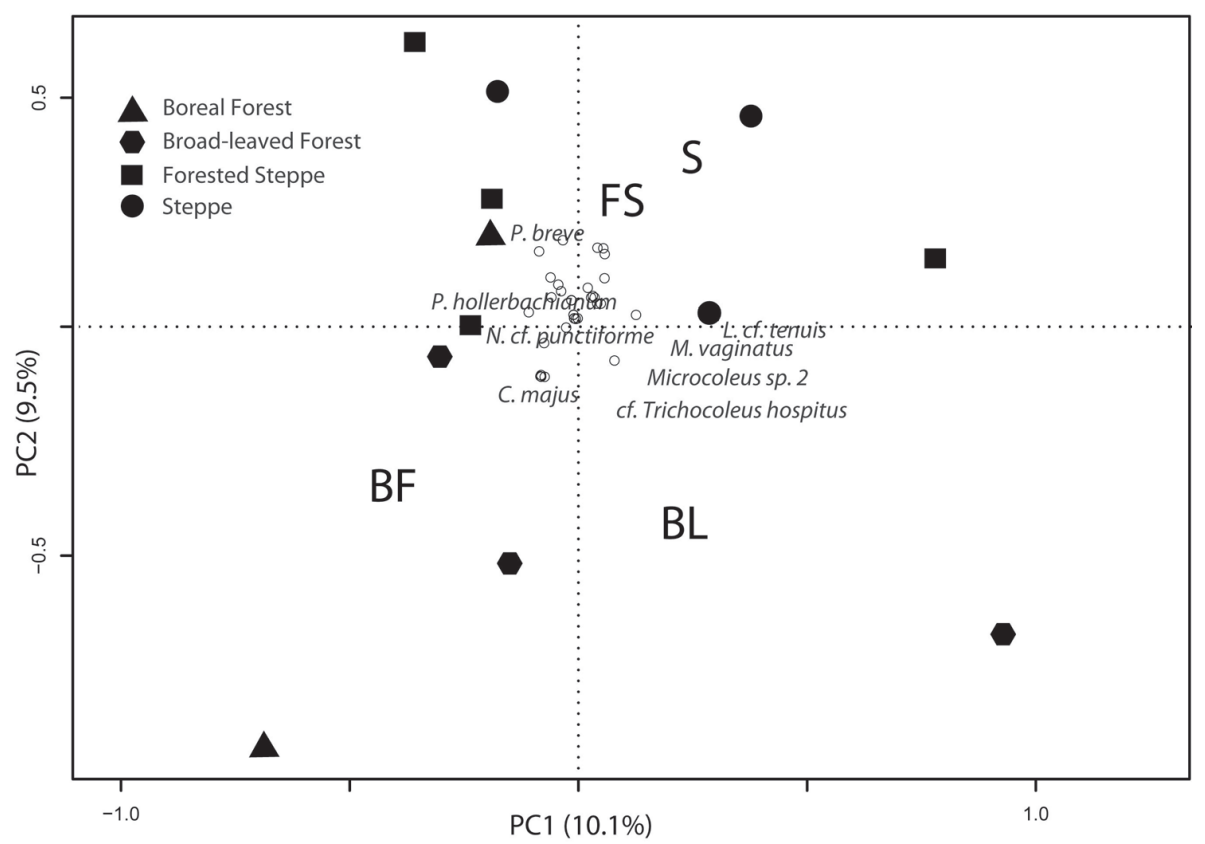

Fig. 58. Principal Component Analysis using Hellinger transformed species data for the combined data from the 12 sites. Community codes (BF, BL, FS, S) are placed in the centroid position of their respective data clouds. Hollow circles represent species, the outer taxa only being named. PC axis 1 roughly corresponds to an aridity gradient (high humidity to left, low humidity to the right), while PC axis 2 roughly corresponds to an organic matter/leaf litter gradient (high organic matter at the bottom, mineral soil at the top). 
Pseudophormidium hollerbachianum and Nostoc cf. commune (Fig. 51) were most abundant in steppe. Leptolyngbya cf. notata was found only in steppe (Fig. 9). Cyanothece aeruginosa was also found in steppe in a sample collected from a forb-grass steppe near Sibay town (Fig. 19, Tables 2, 3). Phormidium cf. jadinianum was detected in the steppe and boreal-forest zones (Fig. 35) (Tables 2, 3).

The principal components analysis (PCA) of the 12 sites suggested that the boreal forest and broad-leaved forest communities were floristically separate, while significant overlap occurred between the forest-steppe and steppe communities (Fig. 58). The centroids for the boreal forest and broad-leaved forest were well away from each other and the forest-steppe and steppe regions. One boreal forest site (site 2) was close to the forest-steppe swarm of sites, while the other boreal forest site (site 1) was very distant from all other sites. The broad-leaved forest has considerably more leaf litter cover than the other three zones, and so it is not surprising to see that this zone is floristically separate. Forest-steppe and steppe zones are more arid and have higher irradiance due to less leaf litter cover. The first two axes of the PCA together explain almost $20 \%$ of the total variation in the community composition. Correlation between PCA scores and factors was not significant $(\mathrm{r} 2=0.376, \mathrm{p}=0.186)$.

\section{DISCUSSION}

In this study of terrestrial cyanobacteria of the South Ural region, in which 56 taxa of cyanobacteria were identified and documented, several unusual taxa were encountered. For example cf. Trichocoleus hospitus is very interesting. It is characterized by thin trichomes (0.6-0.7 $\mu \mathrm{m}$ wide), with cells $0.7-1 \mu \mathrm{m}$ long, solitary or densely aggregated in sheaths $2.5-3.9 \mu \mathrm{m}$ wide. Apical cells are round or thickened. It prefers to grow on the sheaths of other cyanobacteria or in the mucilage of green algae. The assignment of our finding to the genus Trichocoleus could not be confirmed with certainty, because typical cyanobacteria of this genus lack a calyptra or the thickened apical cell observed in the investigated specimen (Fig. 14). Another unusual cyanobacterium found in our sampling area is Chlorogloea cf. purpurea (Fig. 18). This taxon is similar to the description of Chlorogloea purpurea (mucilaginous irregular colonies with pink cells), but it possess smaller cells (0.8$1.5 \mu \mathrm{m}$ in diameter compared with 1.5-2.5 in Chlorogloea purpurea). Additionally, Chlorogloea purpurea is a freshwater species, while our population is from a terrestrial habitat. Myxosarcina cf. tatrica was morphologically similar to the description published by Komárek \& Anagnostidis (1999), but M. tatrica was originally described from a moist rock in Poland. Phormidium cf. jadinianum has trichomes about $6 \mu \mathrm{m}$ wide, constrictions at cross-walls, with acute end cells. It is an unclear, incompletely described species, which was originally described from India (Komárek \& Anagnostidis, 2005). Oxynema cf. acuminatum is also possibly another species, new to science. The morphological features of this species are similar to descriptions: trichomes 3.9-4.3 $\mu \mathrm{m}$ wide, attenuated motile with a relatively rapid oscillation, acute-conical long end cell (Komárek \& Anagnostidis, 2005). But it differs by short cells and very different ecology. Oxynema acuminatum inhabits thermal springs high in salinity or sulfur, whereas this taxon is terrestrial. Several species of the genus Microcoleus were recorded (Table 2, Figs 23-27). Microcoleus sp. 1 is a cyanobacterium putatively new to science. It has long trichomes, 6.7- 
$7.1 \mu \mathrm{m}$ wide, is unconstricted at the cross-walls, is aggregated within sheaths, and is reddish in color. Cells are almost isodiametric. Apical cells are conical, without calyptra. All of the above mentioned unclear species are putative new taxa that should be studied in detail, including molecular characterization in future studies.

Three species of Oculatella (Figs 11-13) were identified and are potentially new to science. Especially interesting is Oculatella sp. 2 with flexuous filaments and sheaths, 2.2-2.6 $\mu \mathrm{m}$ wide, with constrictions at the cross-walls, with more or less isodiametric cells, and with the apical cell widely rounded with slightly sloped crystal-like or orange spot in the apex of the cell (Fig. 12). Despite morphological similarity with some previously described taxa (Zammit et al., 2012; Osorio-Santos et al., 2014), these populations are likely to be separate species based on ecology. Oculatella has a wide distribution in the studied area. Possibly, it was earlier incorrectly identified as Leptolyngbya foveolarum. We found many other populations of Leptolyngbya, which fit Leptolyngbya foveolarum in the keys (blue-green, curved, flexuous, constricted at the cross-walls of the trichomes). Possibly, they represent several cryptic species of this genus. A similar situation occurs in the case of Leptolyngbya voronichiniana with colorless thin sheaths. Another group problematic for identification were Phormidium and Phormidium-like taxa, especially morphotypes with acute-conical apical cells, for example Oxynema cf. acuminatum and Phormidium cf. jadinianum. For correct identification of these taxa, observation of all stages of the life cycle together with understanding of their ecology is crucial. Interesting findings also include Kamptonema animale and K. laetevirens. Kamptonema was recently separated from Phormidium (Strunecký et al., 2014) and this is the first record of these species in the territory of South Ural. Observation of the aquatic Cyanothece aeruginosa in a steppe region is unusual. This taxon is widely distributed in aquatic habitats around the world, but is not common in terrestrial ecosystems (Komárek \& Anagnostidis, 1999). It was reported as Synechococcus aeruginosus Nägeli from shrub-steppe soils in the Great Basin and Columbia Basin of North America (Johansen, 1993). Our finding is a significant addition to the knowledge of the ecology of Cyanothece aeruginosa.

During our investigations, several strains were identified as Scytonema and Tolypothrix. These strains were described in detail by a polyphasic approach in a separate study (Bohunická et al., 2015). It was found that they belong to the new genus Roholtiella, which contained 4 new species, 3 of which were found in the territory of South Ural: Roholtiella bashkiriorum, R. edaphica, and R. fluviatilis (Figs 43-46). An interesting observation was the additional discovery of another Roholtiella type within our collections, characterized by bright green filaments (Fig. 46). It is similar to Roholtiella mojaviensis, but it was isolated from a very different habitat (Bohunická et al., 2015); we provisionally name it here as Roholtiella sp.

Many species of cyanobacteria were previously mentioned in lists of cyanobacteria compiled during floristic studies in the territory of the South Ural. For example, Phormidium ambiguum, Phormidium breve, Phormidium dimorphum, Phormidium retzii, Phormidium tergestinum, Phormidium uncinatum, Leptolyngbya foveolarum, Leptolyngbya voronichiniana, Nostoc commune, Nostoc microscopicum, Nostoc punctiforme, Microcoleus vaginatus, Pseudophormidium hollerbachianum and several other species were recorded in flora of steppe and forest-steppe zones of Bashkiria (Kuzyakhmetov, 1992; Khaibullina et al., 2005; Bakieva et al. 2012). But unfortunately these publications lack information about morphology of taxa, and the taxonomy of many genera has since been revised. This circumstance prevents comparison of previous results with our data. Microcoleus vaginatus, Leptolyngbya 
foveolarum, and Phormidium breve characterized by wide distribution in this study are congruent with previous studies of other regions in Russia (Aleksakhina \& Shtina, 1984) and territories of other countries (Kostikov et al., 2001; Komárek \& Anagnostidis, 2005; Škaloud, 2009; Neustupa \& Škaloud, 2010; Davydov, 2013; Strunecký et al., 2013). Pseudophormidium hollerbachianum, frequently found in this study, is a widely distributed taxon in soils, and was previously found in Russia, Austria, Czech Republic, Denmark, Greece, Poland, and Sweden (Komárek \& Anagnostidis, 2005). Trichormus variabilis, Cylindrospermum majus, Microcoleus autumnalis, and Nostoc microscopicum also have wide distribution, but are possibly sensitive to deficiency of water and high solar insolation.

The combined use of several methods during floristic studies allows identification of more taxa. In our study, cyanobacteria were isolated into strains as well as directly observed on cover slips. It is difficult to isolate some cyanobacteria into pure culture, and the spectrum of species obtained might be limited by this method if used in isolation. For example, cf. Trichocoleus hospitus lives in the mucilage of other organisms, and it is impossible to divide it from those other species. In this case, the cover slip method was useful, because it allowed us to observe the cyanobacterium and to make preliminary identification of the taxon. We also found most of the species of Leptolyngbya only on cover slip surfaces, for example, Leptolyngbya cf. fragilis (Fig. 4), Leptolyngbya cf. subtilissima (Fig. 6), and Leptolyngbya cf. tenuis (Fig. 7).

The differences in the taxonomic composition found in each zone can be attributed to the influence of zonal factors, which have an effect on climate, soil type, and higher plant communities. In this connection, the most important factor was humidity of the substrate. The heterogeneity of the substrate had also considerable impact on the occurrence of the cyanobacterial taxa. In our study, the samples from humid and/or heterogenic conditions were characterized by the highest cyanobacterial diversity (Table 1). The highest number of cyanobacteria, (14 species), was found in sample 59 (Bu12) with visible cyanobacteria and algae growth on the road in the floodplain of the forest-steppe zone. Thirteen species were detected in two samples: sample 17 (P14) from the boreal-forest zone, taken from the riverside of Saldubash river, and sample $53 \mathrm{Bu} 6$ ) from forest-steppe zone from path from the riverside of the Ik River. Twelve species were identified in sample 14 (P11) from a ravine in the boreal-forest zone (Table S1). The importance of humidity as one of the most important ecological factors affecting the soil cyanobacteria was discussed by Gollerbach \& Shtina, (1969). According to their data, the optimal humidity for typical soil algae (including cyanobacteria) is $60-80 \%$ of the full moisture capacity. However, in some species of nitrogen-fixing cyanobacteria, maximal growth was observed at $80-100 \%$ soil humidity.

Species detected only in the boreal-forest zone, such as Aphanothece stagnina, Leptolyngbya cf. hansgirgiana and Kamptonema animale, in general are moisture-loving cyanobacteria (Komárek \& Anagnostidis, 1999, 2005). Cyanobacteria distributed in forest and forest-steppe zones such as Trichormus variabilis and Cylindrospermum majus, were previously reported as more drought-tolerant (Komárek, 2013). Pseudophormidium hollerbachianum and Nostoc cf. commune, abundant in steppes, belong to the subaerophytic species, resistant to water deficiency (Komárek \& Anagnostidis, 2005; Komárek, 2013). Microcoleus vaginatus was dominant in dry soils of steppes, which is in agreement with previous observations that filamentous cyanobacteria from the order Oscillatoriales are the most resistant to drought. Nostoc commune, Scytonema ocellatum and Microcoleus vaginatus form so called "Nostoc-Scytonema coenoces of steppes and semi-deserts" (Gollerbach \& 
Shtina, 1969). Species of Microcoleus were also frequent in the boreal-forest zone, but the population density in steppes was much higher.

The PCA reveals, that steppe and forest-steppe zones were characterized by very similar biodiversity of cyanobacteria (Fig. 58). Species composition of the broad-leaved forest zone is very different. The boreal forest has only two sites, one that is very different from all sites, and one that shares species with the forest-steppe community. The surface soils of these biomes vary along two gradients, soil organic matter/surface leaf litter and humidity, with the most organic and humid soils being boreal forest and the most mineral and dry soils being within steppe.

Influence of microhabitat conditions including heterogeneity of the substrate on terrestrial cyanobacterial diversity has been little studied. E.A. Shtina (1976) mentioned that visible growth of algae and cyanobacteria was detected mostly on sites with irregularities in microtopography. The strong influence of ecotope conditions on soil algae and cyanobacteria has been discussed in several publications (Kuzyakhmetov, 1981, 1992). Possibly, in heterogenic conditions, the cyanobacteria thrive from less competitive conditions with higher plants.

Higher plant communities also may have an impact on the cyanobacterial flora. We did not detect any cyanobacteria in five of the 85 samples $(1,24,25,39$, 45). These samples were collected in different types of forests and plantings (Table 1). Rarity of cyanobacteria in forest soils was also reported by Gollerbach \& Shtina, 1969; Hoffmann et al., 2007 and Khaybullina et al., 2010.

Our results confirm the known assumption that cyanobacteria play an important role in primary colonization of various substrates. In this connection, most prominent are filamentous species. For example, in sample 78 from an abandoned marble quarry in the steppe zone, Leptolyngbya voronichiniana, Leptolyngbya cf. tenuis, Microcoleus vaginatus, Lyngbya martensiana, Phormidium dimorphum and cf. Trichocoleus hospitus were all detected (Tables 1, 3).

Our study reveals that the territory of the South Ural hosts a wide variety of soil cyanobacteria including several taxa potentially new to science. For future molecular-genetic research, the frequently encountered representatives of the genus Microcoleus (Figs 25-27) and Phormidium (Figs 39-40) could be especially interesting.

\section{CONCLUSIONS}

Floristic studies should be the first step in the investigation of biodiversity of cyanobacteria. This type of research allows us to make preliminary assessment of dominant taxa, identify potentially new species and even new genera, and creates a strategy for further molecular-genetic research. To our knowledge, for Chlorogloea cf. purpurea and several species of Oculatella, this is the first record of their presence in the territory of the South Ural region. Strains obtained in this study will provide a valuable starting point for future molecular studies.

Acknowledgements. This study was supported by the Russian Foundation for Basic Research in frame of project 16-04-01511 a. We are thankful to Yunir Gabidullin for helping us in preparation of the figure plates and the map of the sampling sites. M. Bohunická and J.R. Johansen were supported by grant number 15-11912S from the Czech Science Foundation. 


\section{REFERENCES}

ABDULLIN S.R. \& SHARIPOVA M.YU., 2004 - Studies of algae in the Shulgan-Tash (Kapova) Cave, South Ural, Russia. Cave and karst science 31: 83-96.

ABDULLIN S.R., 2009 - Cyanobacterial-algal cenoses of the Shulgan-Tash Cave, Southern Urals. Russian journal of ecology 40: 301-303.

ADHIKARY S.P., 2000 - Epilithic cyanobacteria of exposed rocks and walls of temples and monuments of India. Indian journal of microbiology 40: 67-81.

AKHMADEYEVA L., 2003 - Neurological letters from... Bashkortostan. Practical neurology 3 (6): 380-382.

ALEKSAKHINA T.I. \& SHTINA E.A., 1984 - Soil Algae of Forest Ecosystems. Moscow, Nauka, $150 \mathrm{p}$.

ALEKSEEV YU.E., ALEKSEEV E.B., GABBASOBV K.K. et al. (eds), 1988 - Opredelitel vysshikh rasteniy Bashkirskoy ASSR [The key-book of high plants of Bashkirskaya ASSR]. Moscow, Nauka: 3-23.

ANAGNOSTIDIS K. \& KOMÁREK J., 1988 - Modern approach to the classification system of cyanophytes 3 - Oscillatoriales. Algological studies 50-53: 327-472.

BAKIEVA G.R., KHAIBULLINA L.S., GAISINA L.A. \& KABIROV R.R., 2012 - Ecological -floristic analysis of soil algae and cyanobacteria on the Tra-Tau and Yurak-Tau Mounts, Bashkiria. Eurasian soil science 9: 974-982.

BISCHOFF H.W. \& BOLD H.C., 1963 - Phycological studies. IV. Some soil algae from Enchanted Rock and related algal species. University of Texas Publications 6318, Austin, 95 p.

BOHUNICKÁ M., PIETRASIAK N., JOHANSEN J.R., BERRENDERO-GÓMEZ E., HAUER T., GAYSINA L.A. \& LUKEŠOVÁ A., 2015 - Roholtiella, gen. nov. (Nostocales, Cyanobacteria) - a tapering and branching cyanobacteria of the family Nostocaceae. Phytotaxa 197: 84-103.

BRAUN-BLANQUET J., 1951 - Pflanzensociologie. Wien, Springer.

DAVYDOV D., 2013 - Diversity of the Cyanoprokaryota in polar deserts of Rijpfjorden east coast, North-East Land (Nordaustlandet) Island, Spitsbergen. Algological studies 142: 29-44.

DUBOVIK I.E., 2000 - Transformation of algocenoses in eroded soils of the forest-steppe zone. Eurasian soil science 33: 841-846.

DUBOVIK I.E., 2001 - Effects of erosion control measures on the development of algae in soils of the Cis-Ural forest-steppe. Eurasian soil science 34: 759-764.

DUBOVIK I.E., 2010 - Cyanophyta in anthropogenically-destroyed soils of Republic of Bashkortostan. Botanicheskii zhurnal 95: 3.

GOLLERBACH M.M. \& SHTINA E.A., 1969 - Pochvennyje vodorosli [Soil algae]. Leningrad, Russia, Nauka, $228 \mathrm{p}$.

GUIRY M.D. \& GUIRY G.M., 2016 - AlgaeBase. World-wide electronic publication, National University of Ireland, Galway. http://www.algaebase.org; searched on 31 December 2016.

HAUER T., 2007 - Rock-inhabiting cyanoprokaryota from South Bohemia (Czech Republic). Nova Hedwigia 85: 379-392.

HAUER T., 2008 - Epilithic cyanobacterial flora of Mohelenska hadcova steppe nature reserve (western Moravia, Czech Republic) 70 years ago and now. Fottea 8: 129-132.

HOFFMANN L., ECTOR L \& KOSTIKOV I., 2007 - Algal flora from limed and unlimed forest soils in the Ardenne (Belgium). Systematics and geography of plants 77: 15-90.

JOLLIFFE I.T., 1986. - Principal Component Analysis. Berlin, Springer-Verlag, 485 p.

JOHANSEN J.R., 1993 - Minireview: cryptogamic crusts of semiarid and arid lands of North America. Journal of phycology 29: 139-147.

KABIROV R.R. \& LUBINA S.V., 1988 - Method for evaluation of herbicides on communities of soil algae by indicator species. Agrochemistry 3: 105.

KABIROV R.R., GAISINA L.A. \& SAFIULLINA L.M., 2010 - Universal criteria for assessing the ecological state of soil algocenoses. Russian journal of ecology 41: 302-306.

KHAIBULINA L.S., SUKHANOVA N.V., KABIROV R.R. \& SOLOMESHCH A.I., 2005 Syntaxonomy of communities of soil algae in the Southern Ural. 3. Class BracteacoccoHantzschietea cl. nov. International journal on algae 7: 281-298.

KHAYBULLINA L.S., GAYSINA L.A., JOHANSEN J.R. \& KRAUTOVÁ M., 2010 - Examination of the terrestrial algae of the Great Smoky National Park, USA. Fottea 10 (2): 201-215.

KHAZIYEV F.KH., 2012 - Ekologiya pochv Bashkortostana [Ecology of soils of Bashkortostan]. Ufa, Gilem, 2012. 312 p. 
KIREEVA N.A., DUBOBIK I.E. \& ZAKIROVA Z.R., 2007 - Consortial associations of cyanobacteria in a typical chernozem contaminated with oil. Eurasian soil science 40: 675-680.

KOMÁREK J. \& ANAGNOSTIDIS K., 1999 - Cyanoprokaryota. 1. Teil: Chroococcales. In: Ettl H., Gärtner, G. Heynig H. \& Mollenheuer, D. (eds), Süßwasserflora von Mitteleuropa, Bd. 19/1. Berlin, Spektrum Akademische Verlag GmbH, Heidelberg, 548 p.

KOMÁREK J. \& ANAGNOSTIDIS K., 2005 - Cyanoprokaryota. 2. Teil/2 $2^{\text {nd }}$ Part: Oscillatoriales. In: Büdel, B., Krienitz, L., Gärtner, G. \& Shagerl, M. (eds), Süßwasserflora von Mitteleuropa, Bd. 19/2. München, Spektrum Akademische Verlag, Elsevier GmbH, 759 p.

KOMÁREK J., 2013 - Cyanoprokaryota. 3. Heterocytous genera. In: Büdel B., Gärtner G., Krienitz L., Schagerl M. (eds), Süswasserflora von Mitteleuropa - Freshwater flora of Central Europe. Berlin, Heidelberg, Springer Verlag, $1130 \mathrm{p}$.

KOMÁREK J., KAŠTOVSKYY J., MAREŠ J. \& JOHANSEN J.R., 2014 — Taxonomic classification of cyanoprokaryotes (cyanobacterial genera) using a polyphasic approach. Preslia 86: 295-335.

KOSTIKOV I.J., ROMANENKO P.O., DEMCHENKO E.M., DARIENKO T.M., MIKHAYLJUK T.I., RYBCHINSKIY O.V. \& SOLONENKO A.M., 2001 - Vodorosti gruntiv Ukrajiny [Soil algae of Ukraine]. Kiev, Phytosotsiologichniy center, $300 \mathrm{p}$.

KUZYAKHMETOV G.G., 1981 - Analiz gorizontal'noy neodnorodnosti al'gosinuziy, svyazannoy s nanorel'yefom [Analysis of horizontal heterogeneity of algosinusia, connected with nanorelief]. Botanicheskii zhurnal 66 (6): 815-825.

KUZYAKHMETOV G.G., 1992 - Algae of zonal steppe and forest-steppe soil source. Eurasian soil science 24: 35 .

KUZYAKHMETOV G.G., 1998 - Productivity of algocenoses in zonal arable soils of steppe and forest-steppe. Eurasian soil science 31: 406-410.

LEGENDRE P. \& GALLAGHER E.D., 2001 - Ecologically meaningful transformations for ordination of species data. Oecologia 129: 271-280.

LUND J.W.G., 1945 - Observations on soil algae. 1. The ecology, size and taxonomy of British soil diatoms. New phytologist 44 (2): 169-216.

NEUSTUPA J. \& ŠKALOUD P., 2010 - Diversity of subaerial algae and cyanobacteria growing on bark and wood in the lowland tropical forests of Singapore. Plant ecology and evolution 143: 51-62.

OKSANEN J., BLANCHET F.G., FRIENDLY M., KINDT R., LEGENDRE P., MCGLINN D., MINCHIN P.R., O'HARA R.B., SIMPSON G.L., SOLYMOS P., STEVENS M.H.H., SZOECS E. \& WAGNER H., 2017 - Vegan: Community Ecology Package. R package version 2.4-5.

OSORIO-SANTOS K., PIETRASIAK N., BOHUNICKÁ M., MISCOE L.H., KOVACIK L., MARTIN M.P. \& JOHANSEN J.R., 2014 - Seven new species of Oculatella (Pseudanabaenales, Cyanobacteria): taxonomically recognizing cryptic diversification. European journal of phycology 49: 450-470.

PRIKHOD'KO V.E., IVANOVA I.V., MANAKHOV D.V., MANAKHOVA E.V., 2012 - Soil and the soil cover of the Arcaim reserve (steppe zone of the Transural region). Eurasian soil science 45 (8): 725-739.

R CORE TEAM, 2017 - R: A language and environment for statistical computing. R Foundation for Statistical Computing, Vienna, Austria. https://www.R-project.org/.

SAYFULLINA Z.N. \& MINIBAEV R.G., 1980 - Vliyaniye orosheniya na pochvennyye vodorosli [Influence of irrigation on soil algae]. Botanicheskii zhurnal 65: 1613.

SHARIPOVA M.YU., 1997 - Structure formation of algal communities in model algocenoses exposed to lead pollution. Russian journal of ecology 28: 191-193.

SHARIPOVA M.YU., 2007 - Algological assessment of ecotonal communities in zones of industrial pollution. Russian journal of ecology 38: 135-139.

SHMELEV N.A. \& KABIROV R.R., 2007 - Communities of soil algae of basic forest types of SouthUral reserve. Russian forest sciences 1: 20-27.

SHTINA E.A., 1976 - Prichiny i indikatornoye znacheniye "tsveteniya pochvy" [Causes and indicator value of soil "flowering"]. In: Biological diagnostic of soils. Moscow, pp. 313-314.

ŠKALOUD P., 2009 - Species composition and diversity of aero-terrestrial algae and cyanobacteria of the Boreč Hill ventaroles. Fottea 9 (1): 65-80.

STRUNECKÝ O., KOMÁREK J. \& ŠMARDA J., 2014 - Kamptonema (Microcoleaceae, Cyanobacteria), a new genus derived from the polyphyletic Phormidium on the basis of combined molecular and cytomorphological markers. Preslia (Prague) 86: 193-207.

STRUNECKÝ O., KOMÁREK J., JOHANSEN J.R, LUKEŠOVÁ A. \& ELSTER J., 2013 - Molecular and morphological criteria for revision of the genus Microcoleus (Oscillatotiales, Cyanobacteria). Journal of phycology 49: 1167-1180. 
SUKHANOVA N.V. \& ISHBIRDIN A.R., 1997 - Syntaxonomy of soil algae of urban territories of Bashkir Preduralye (Russia). Journal of algology 7: 18.

TAHAEV H.YA., 1959 - Prirodnuye usloviya i resursy Bashkirskoy ASSR [Nature conditions and resources of Bashkirskaya ASSR]. Ufa, Bashkir publishing house, $296 \mathrm{p}$.

VINOGRADOVA O.N., POEM-FENKEL M., NEVO E., WASSER S.P., 2000 - Diversity of Cyanoprocaryota in Israel. First data about blue-green algae of dry limestone of upper Galilee. International journal of algae 2: 27-45.

ZAMMIT G., BILLI D. \& ALBERTANO P., 2012 - The subaerophytic cyanobacterium Oculatella subterranea (Oscillatoriales, Cyanophyceae) gen. et sp. nov.: a cytomorphological and molecular description. European journal of phycology 47: 341-354. 